\title{
15. ORIGIN OF LOWER EOCENE PALYGORSKITE CLAYS ON THE CÔTE D'IVOIRE-GHANA TRANSFORM MARGIN, EASTERN EQUATORIAL ATLANTIC ${ }^{1}$
}

\author{
Thomas Pletsch ${ }^{2}$
}

\begin{abstract}
Palygorskite was identified in lower Eocene clays and porcellanites in Holes 959D, 960A, 960C, and 961A; in upper Albian to Cenomanian clays with chert in Hole 962B; and in undated clays in Holes 962B and 962C of Ocean Drilling Program Leg 159. Palygorskite is particularly abundant in lower Eocene bluish claystones of Sites 960 and 961 , which reach 20 to $30 \mathrm{~m}$ in thickness. Based on the microscopic texture, the mineralogical purity of the palygorskite clays, and on growth relationships, palygorskite is interpreted to be of authigenic or very early diagenetic marine origin. The lack of typical detrital lithologies or of sedimentary structures related to resedimentation and the scarcity of clearly terrigenous minerals also argues for in situ formation. Micropaleontologic data indicate that palygorskite formation took place in deep-sea environments with no indication of significant shallowing. The transformation of pre-existing clay minerals at or closely below the sediment/seawater interface seems to be responsible for the formation of palygorskite clay on the Côte d'Ivoire-Ghana Transform Margin.

Palygorskite frequently occurs in lower Eocene sediments of equatorial to subtropical paleolatitudes. The formation of authigenic palygorskite clays at the Leg 159 drill sites is interpreted to be the result of elevated deep-sea temperatures and Mgand Si-rich deeper waters. The occurrence of authigenic, deep-marine palygorskite in space and time may correspond to the areas and to the time periods, respectively, of warm, saline deep-water production.
\end{abstract}

\section{INTRODUCTION}

The recovery during Ocean Drilling Program Leg 159 of blue palygorskite clays at the transition from Upper Cretaceous and lower Paleogene carbonate-bearing facies to middle Eocene and younger siliceous deposits has attracted much attention (Fig. 1). The peculiar mineralogy and the microfossils that were found in the palygorskite clays have led to speculations about their presumable origin. Benthic foraminifers in these clays consistently point to deep-water conditions, thus excluding the possibility of a terrestrial or shallow-marine depositional environment. However, no agreement was reached as to whether palygorskite formed at the seafloor or whether it entered the basin as a detrital particle derived from land or shallow lagoons (Shipboard Scientific Party, 1996b).

Palygorskite, also known as attapulgite, is a magnesium-rich hydrous aluminum silicate and belongs to the fibrous clay minerals group. This group also includes sepiolite, which is more magnesian and contains less aluminum than palygorskite. In contrast to common phyllosilicates, palygorskite and sepiolite have a ribbon structure that is responsible for their fibrous habit. The crystallography, chemical composition, physical properties and aspects of their geological occurrence have been reviewed by Brindley and Brown (1980), Kastner (1981), Jones and Galán (1988), and Singer (1989). Palygorskite and sepiolite usually are only a minor component of modern sediments and soils. Only in specific environments do they occur in large amounts (see below). In this paper, the term "palygorskite clay" is used to describe clays that are rich in palygorskite, but that may also contain significant amounts of other clay minerals.

Palygorskite has been used as a mineral indicator for arid or semiarid continental climates because, on the continents, it typically occurs in calcareous soils of arid areas, calcretes and coastal sabkhas (e.g., Singer, 1984; Chamley, 1989; Weaver, 1989). These environments are characterized by a constant or seasonal dominance of evap-

${ }^{1}$ Mascle, J., Lohmann, G.P., and Moullade, M. (Eds.), 1998. Proc. ODP, Sci. Results, 159: College Station, TX (Ocean Drilling Program).

${ }^{2}$ Geologisch/Paläontologisches Institut, Christian-Albrechts-Universität Kiel, Olshausenstr. 40, 24118 Kiel, Federal Republic of Germany.

tp@zaphod.gpi.uni-kiel.de oration over precipitation or by fluctuating groundwater levels, which lead to the enrichment of $\mathrm{Mg}$ - and $\mathrm{Si}$-ions in alkaline interstitial solutions (Singer, 1979, 1989, and references therein). Palygorskite formation in arid soils strongly depends on the enrichment of these ions at a $\mathrm{pH}$ of 8 to 9 ; salinity appears to play a lesser role, but is generally high (Stengele, 1997). Even if palygorskite is reworked from underlying sedimentary formations, it indicates arid terrestrial climate at the time of erosion because it is unstable at annual precipitation rates exceeding $300 \mathrm{~mm}$ per year and probably transforms into smectite (Paquet, 1970).

In present-day seas, palygorskite most widely occurs in offshore arid regions where modern or fossil palygorskite-bearing formations are subject to erosion. In many of these cases, it has been demonstrated that palygorskite was transported as a detrital particle to the sea by rivers or by wind (e.g., Hartmann et al., 1971; Lange, 1975; Chamley et al., 1977; Coudé-Gaussen and Blanc, 1985; Sirocko and Lange, 1991; Fagel et al., 1992). Since palygorskite is stable in seawater (Weaver and Beck, 1977), it appears that, in marine basins, palygorskite lends itself to paleoclimatic reconstruction because it indicates aridity in the continental source area of the marine sediments.

However, palygorskite also occurs in very distal marine sediments (i.e., in the central parts of the Atlantic and Pacific Oceans) and in other oceanic environments where fluvial or eolian input is thought to be negligible (e.g., Bonatti and Joensuu, 1968; Bowles et al., 1971; Berger and von Rad, 1972; Couture, 1977, 1978; Church and Velde, 1979; Natland and Mahoney, 1982; Karpoff et al., 1989; Gibbs et al., 1993; Thiry and Jacquin, 1993). These occurrences were explained as resulting from authigenic, diagenetic, or hydrothermal processes including the alteration of pre-existing sediments under warm, Si-rich conditions, the alteration of oceanic basalt or serpentinites, or the direct precipitation from interstitial solutions in veins or in the pore space of sediments. If palygorskite can form at the seafloor or just below, its straightforward use as a paleoclimatic indicator is not warranted because its formation would reflect sea bottom instead of earth-surface environmental conditions. The genesis and paleoclimatic significance of fossil palygorskite in marine deposits, therefore, remains a matter of vigorous debate.

Interest in the origin of palygorskite may arise from its abundance and widespread occurrence at low latitudes close to the Paleocene/ 


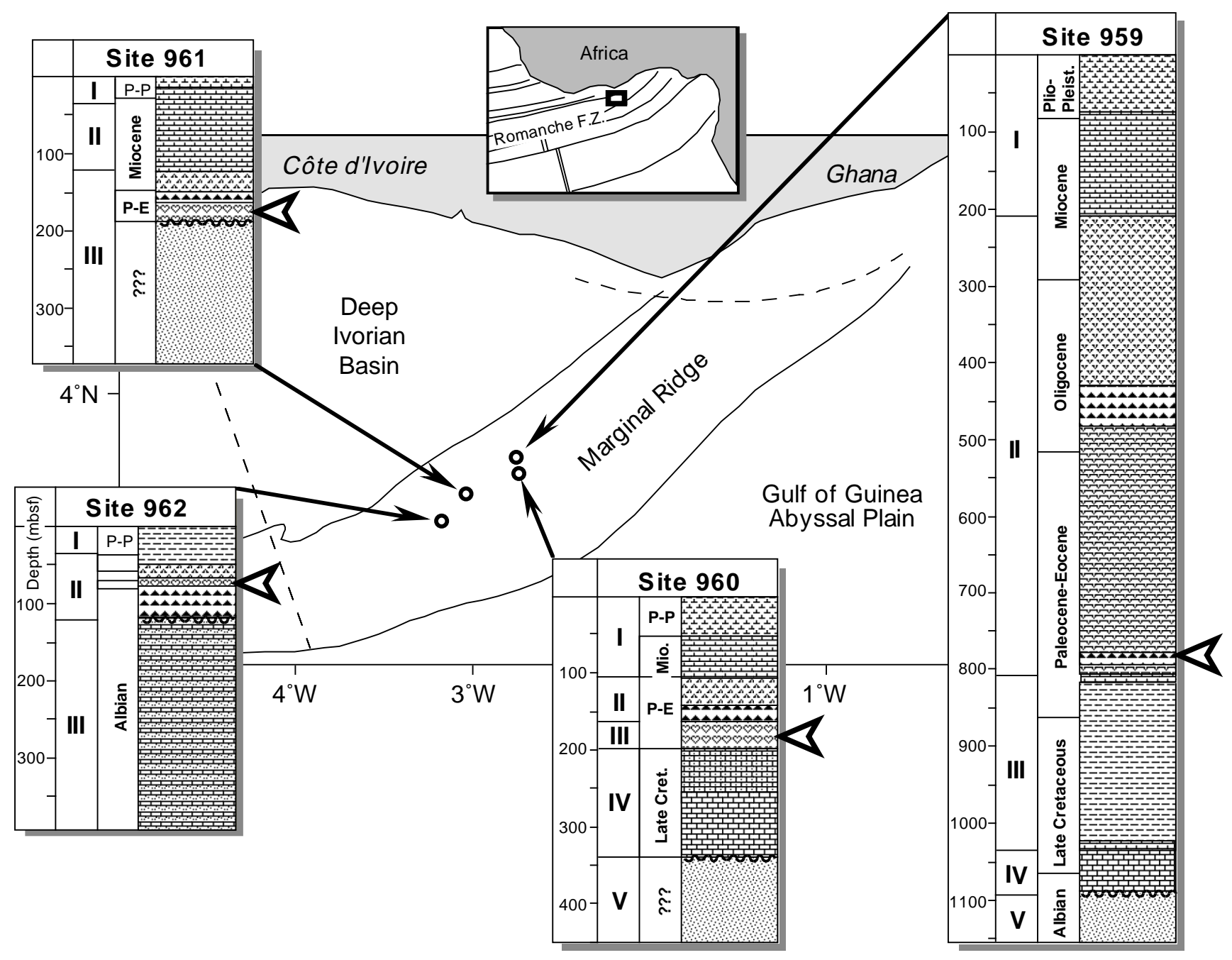

Figure 1. Location of ODP Leg 159 drill sites. Columns display generalized stratigraphy, lithologic units and lithology of the recovered sediments. Insert shows location of the drill sites at the intersection of the Romanche Fracture Zone with the African continental margin. Arrows indicate palygorskite intervals. $\mathrm{P}-\mathrm{P}=$ Pliocene-Pleistocene, Mio. $=$ Miocene, $\mathrm{P}-\mathrm{E}=$ Paleocene-Eocene. For explanation of symbols refer to Mascle, Lohmann, Clift, et al. (1996).

Eocene boundary (Robert and Chamley, 1991). Starting in the late Paleocene, a long-term warming trend of both oceanic surface and deep waters and a concurrent change in ocean circulation has been deduced from stable oxygen isotopes of planktonic and benthic foraminifers (review in Zachos et al., 1993, 1994; Corfield, 1994). On the continents, a generally warmer climate and an extension of warm conditions into high latitudes have been inferred on the basis of paleontologic and isotopic evidence (e.g., Greenwood and Wing, 1995). The reasons for the inferred changes in oceanic and continental circulation and global heat transfer, however, remain speculative. This is partly because critical proxy evidence from low-latitude regions is scarce or unreliable. Isotopic studies of tropical paleotemperatures are hampered by the unknown salinity of the surface waters, in particular in low-latitude marginal marine environments where evaporation exceeded precipitation (Railsback et al., 1989; Zachos et al., 1993, 1994). More information on the climatic and paleoceanographic conditions of these regions is needed, because it was proposed that warm, saline deeper waters that had potentially driven early Eocene circulation originated in these areas (Kennett and Stott, 1990). As suggested for the Cretaceous by Couture (1978) and Thiry and Jacquin (1993), palygorskite growth is favored under warm, ion-enriched conditions and, consequently, palygorskite in lower Eocene sediments might serve as an indicator for the sites where warm, saline waters reached down to the seafloor. To understand the paleoclimatic implications of palygorskite deposits, it is imperative to know whether they represent detrital input and would thus be related to the terrestrial paleoclimate, or whether they were formed authigenically at the seafloor, potentially driven by the oceanographic changes of the early Eocene. An investigation of the origin of lower Eocene palygorskite is, therefore, highly pertinent to a better knowledge of low-latitude climate during the Paleocene-Eocene thermal maximum.

The aim of the present study is to document texture and mineralogy of the palygorskite clays and correlative sediments of Leg 159 based on X-ray diffraction (XRD) analyses and scanning electron microscope (SEM) observations. The focus will be on the purest, lower Eocene palygorskite claystones recovered from Holes 960A, 960C, and 961A. A tentative model is presented that integrates the contrasting modes of palygorskite occurrence with the paleoclimatic situation of the early Eocene.

\section{GEOLOGICAL SETTING AND PREVIOUS STUDIES}

During Leg 159, 13 holes were drilled at four sites on the Côte d'Ivoire-Ghana Transform Margin (CIGTM) in water depth ranging from 2090 to 4650 m (Mascle, Lohmann, Clift, et al., 1996). All sites 
are located along the strike of the Marginal Ridge (MR), an elongate basement ridge that separates the Deep Ivorian Basin (DIB) from the Gulf of Guinea Abyssal Plain (GGAP). Site 959 is situated at the southern margin of the DIB. Site 960 is only $5.5 \mathrm{~km}$ to the south of Site 959 on top of the MR. Site 961 is located on a deeper basement elevation of the MR, and Site 962 was placed on a minor ridge farther southwest (Fig. 1).

The MR probably acted as a morphologic barrier throughout the Cretaceous to the Holocene of the CIGTM. Marine conditions were established by the late Aptian-early Albian at Sites 959 and 962 (Holbourn and Moullade, Chap. 28, this volume). Between the Albian and Coniacian, coarse-grained detrital carbonates at Sites 959 and 960 testify to the development of adjacent carbonate platforms, probably on top of the MR (Watkins et al., Chap. 26, this volume). For the remaining part of the Late Cretaceous and early Paleocene, strongly reduced sedimentation rates and/or current sweeping allowed only a few meters of sediment to be deposited at Sites 960, 961, and 962. These sediments, replete with hardgrounds and glauconitic layers, are overlain by 3 to as much as $50 \mathrm{~m}$ of palygorskite-bearing uppermost Paleocene and lower Eocene sediments. At Site 959, however, there was continuous sedimentation of $230 \mathrm{~m}$ of black, carbonaceous claystones of Santonian to late Paleocene age, and only a single sample at the transition from the black claystones to the overlying, middle Eocene sediments has yielded palygorskite. At this site, the paleoenvironment changed from restricted, marginal marine conditions to deeper water hemipelagic, siliceous sedimentation (Kuhnt et al., Chap. 31, this volume). Similarly, the palygorskite-bearing intervals at the other sites are overlain by siliceous, often zeolite-bearing deposits of middle Eocene or younger age.

Western African coastal basins and, in particular, the northern shelf of the Gulf of Guinea are classical areas for the study of palygorskite in Paleocene-Eocene sediments. Skansky (1958) and Skansky et al. (1959) described the stratigraphy and clay mineralogy of exploration wells in the Côte d'Ivoire basin, which is the proximal part of the Côte d'Ivoire-Ghana Transform Margin, and in the Dahomey-Togo basin, some $600 \mathrm{~km}$ to the northeast. In the Côte d'Ivoire basin, they report the occurrence of abundant palygorskite and sepiolite throughout $500 \mathrm{~m}$ of Paleocene to lower middle Eocene shallow marine sediments. In the Dahomey-Togo basin, palygorskite was found in marine sediments with neritic and pelagic fossils of a latest Paleocene to early Eocene age. The palygorskite-bearing interval thickens from 100 to $150 \mathrm{~m}$ toward the distal part of the basin. In both basins, there were two pronounced maxima near the top and the base of the palygorskite series. Millot $(1964,1970)$ discussed clay mineral results from West African sedimentary basins, including the above. He concluded that the late Paleocene to early middle Eocene was a privileged time for palygorskite and sepiolite formation. Millot proposed that these minerals formed during an early Eocene period of tropical humidity. Intense leaching and the formation of laterites in the continental hinterlands would have brought about the input of abundant dissolved elements (including $\mathrm{Si}$ and $\mathrm{Mg}$ ) into lacustrine and marine basins. These elements would have precipitated as carbonates, phosphates, siliceous deposits, or as magnesium-rich clay minerals such as palygorskite and sepiolite.

\section{MATERIALS AND METHODS}

More than 400 samples at a minimum spacing of one sample per core were selected from cores drilled during Leg 159 for shore-based XRD analysis of the clay-sized fraction. Palygorskite was detected in 34 of these samples based on the presence of characteristic reflections relating to lattice spacings around $\mathrm{d}=10.5 \AA$, $6.4 \AA, 5.4 \AA, 4.5 \AA$, and $3.2 \AA$. All samples were dried at temperatures below $50^{\circ} \mathrm{C}$ and disaggregated in water. The slurry was washed through a $63-\mu \mathrm{m}$ sieve to remove the sand-sized fraction, which was checked using a binocular microscope and further used for micropaleontologic studies. If disag- gregation in water was insufficient, the samples were dried again, immersed in dilute (c. $10 \%) \mathrm{H}_{2} \mathrm{O}_{2}$, and the resulting fine material added to the previous suspension. Suspensions were treated with $0.2 \mathrm{~N}$ hydrochloric acid to remove carbonates. This process was performed while the suspension was kept constantly agitated and the $\mathrm{pH}$ checked to avoid irregular or overly long exposure to the acid. The decarbonated suspensions were washed five to 20 times with demineralized water to remove excess ions. If after 20 washings the clay still flocculated, one drop of $30 \% \mathrm{HNO}_{3}$ was added. This treatment always led to dispersion of the clays. Separation of the clay-sized fraction $(<2 \mu \mathrm{m})$ was achieved by sedimentation in glass jars and subsequent inhalation of the upper $1.5 \mathrm{~cm}$ with a syringe. Stoke's law was applied for the determination of the settling times. The clay fraction was concentrated in a centrifuge, and the resulting paste was spread into a calibrated recess cut into common glass slides.

Preparation and measurements were performed at the Laboratoire de Sédimentologie et Géodynamique, Université de Lille, France, according to the routine procedures used in that laboratory (Holtzapffel, 1985). A Philips PW1710 diffractometer equipped with a $\mathrm{Cu}$ tube and a Ni monochromator was used with the following settings: $40 \mathrm{kV} /$ $25 \mathrm{~mA}$ generator tension/current, $1^{\circ}$ fixed divergence slit, $0.1^{\circ}$ receiving slit, sample spinner on. All samples were scanned three times in step-scan mode with $1 \mathrm{~s}$ per step of $0.02^{\circ} 2 \Theta$, air-dried and glycolated (12 hr under vacuum at room temperature) mounts from $2.5^{\circ}$ to $32.5^{\circ}$ $2 \Theta$, and heated mounts $\left(2 \mathrm{hr}\right.$ at $\left.490^{\circ} \mathrm{C}\right)$ from $2.5^{\circ}$ to $14.5^{\circ} 2 \Theta$. No mineral percentages were calculated from the X-ray diffraction data, but the original diffractograms are shown. This approach was chosen because it is problematic to obtain meaningful numerical values from $\mathrm{X}$-ray intensities of oriented mounts made from mixtures of minerals with different crystal habits and structures, as is the case for fibrous palygorskite and other, flaky phyllosilicates (Moore and Reynolds, 1989; López Galindo et al., 1996).

Additional samples were available from splits of the shipboard micropaleontology samples. These were often too small for clay separation and were only prepared for bulk-rock XRD and SEM. Bulkrock samples and aliquots of most clay samples from the palygorskite-bearing intervals were analyzed at the Geologisch-Paläontologisches Institut (GPI) and Geomar Center for Marine Research of the University of Kiel on diffractometers with different settings for comparison, but are not shown here. Electron microscopic observations were performed on a CamScan scanning electron microscope with a coupled EDAX energy dispersive spectrometer (EDS) at beam currents between 15 and $20 \mathrm{kV}$ at GPI. Samples for SEM were not treated with water or chemicals, but dried at room temperature and mounted on aluminum stubs with a two-component glue. The glue was cured overnight at temperatures below $50^{\circ} \mathrm{C}$. The sample was then broken above the glue and coated with carbon and a gold/palladium alloy.

Onboard determination of palygorskite was made using the ship's diffractometer (Shipboard Scientific Party, 1996a). In smear slides, we found that aggregates of palygorskite clay (as determined from bulk-rock XRD) showed a characteristic, rectangular extinction pattern under the polarizing microscope that was not observed in samples without palygorskite. In the present study, however, this criterion was used only to indicate the presence of palygorskite in one interval, where sampling was restricted to smear slides.

\section{RESULTS}

Palygorskite was identified only in specific intervals of Holes 959D, 960A, 960C, 961 A, 962B, and 962C, which will be referred to as the "palygorskite intervals" (Fig. 2). Age assignments in the following documentation of the lithology, XRD results, and SEM observations of samples from these intervals are based on shipboard biostratigraphic determinations (Mascle, Lohmann, Clift, et al., 1996) and on data by Erbacher (Chap. 29, this volume). The reported biostratigraphic data may be subject to further refinements (see Bignot, 
Chap. 33; Oboh-Ikuenobe et al., Chap. 25; Shafik et al., Chap. 32, all this volume).

\section{Hole 959D}

In Hole 959D, at a present water depth of $2091 \mathrm{~m}$, palygorskite was identified in a single sample (159-959D-39R-4, 66-70 cm, 778.96 mbsf), but it was not detected in samples above and below (Fig. 2). The age is between early Eocene calcareous nannoplankton Subzones CP9b and CP10 (Shipboard Scientific Party, 1996c). The sample is from a light greenish gray (5G 6/1 to $5 \mathrm{G} 5 / 1$ ) interval, which, according to smear slides and bulk-rock XRD, consists mostly of micritic calcite and diagenetic microquartz with calcareous nannofossils.

\section{Hole 960A}

In Hole 960A, at less than $6 \mathrm{~km}$ distance to Site 959 and in a present water depth of $2048 \mathrm{~m}$, the palygorskite interval lies between $\sim 175$ and 125 mbsf. Palygorskite-rich clay, however, is confined to a
Hole 959D

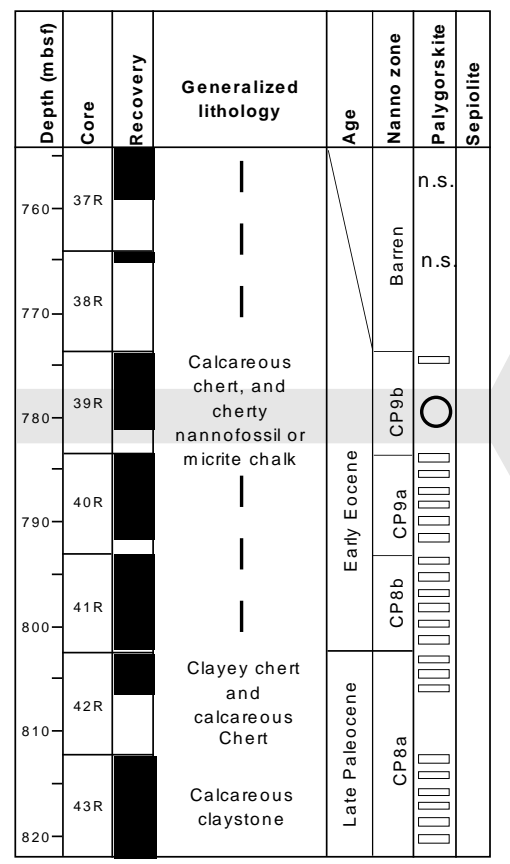

Hole 960A

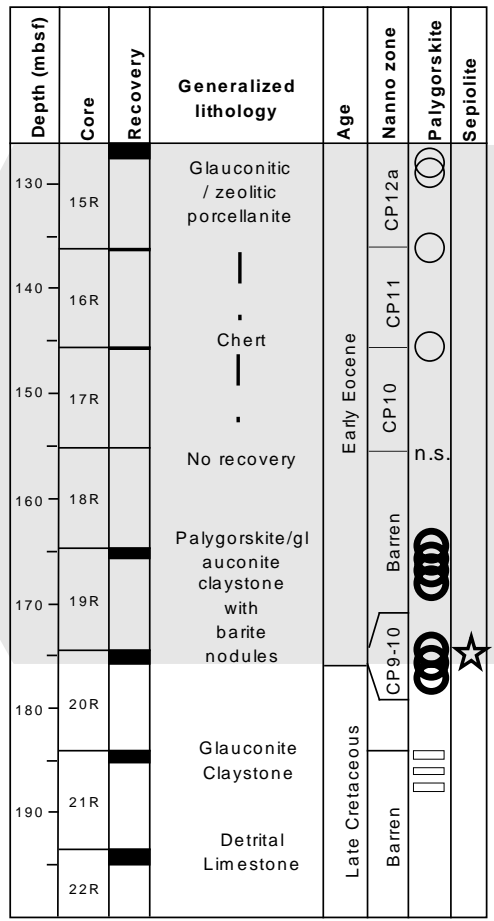

Hole 960C

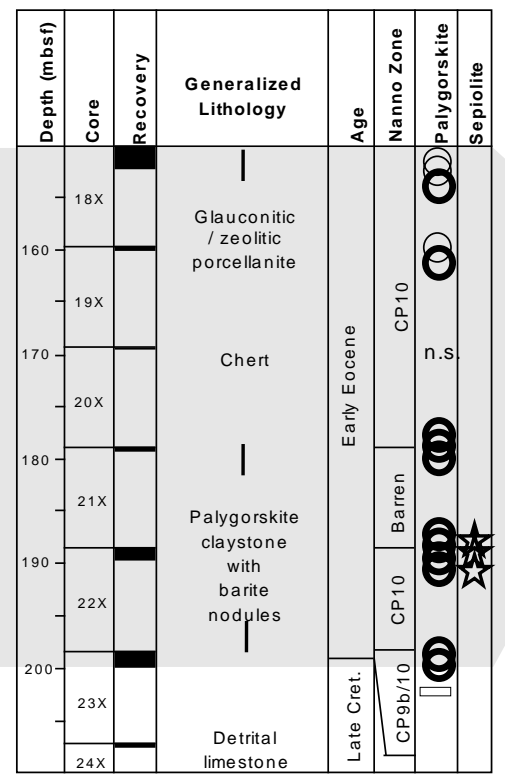

Hole 961A

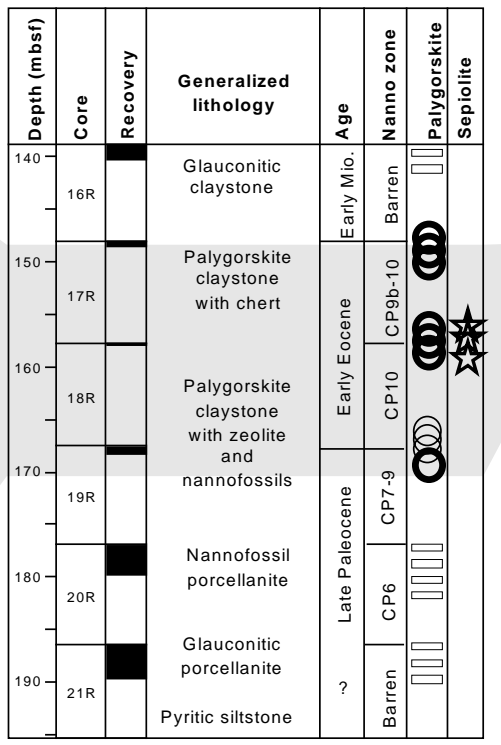

Hole 962B
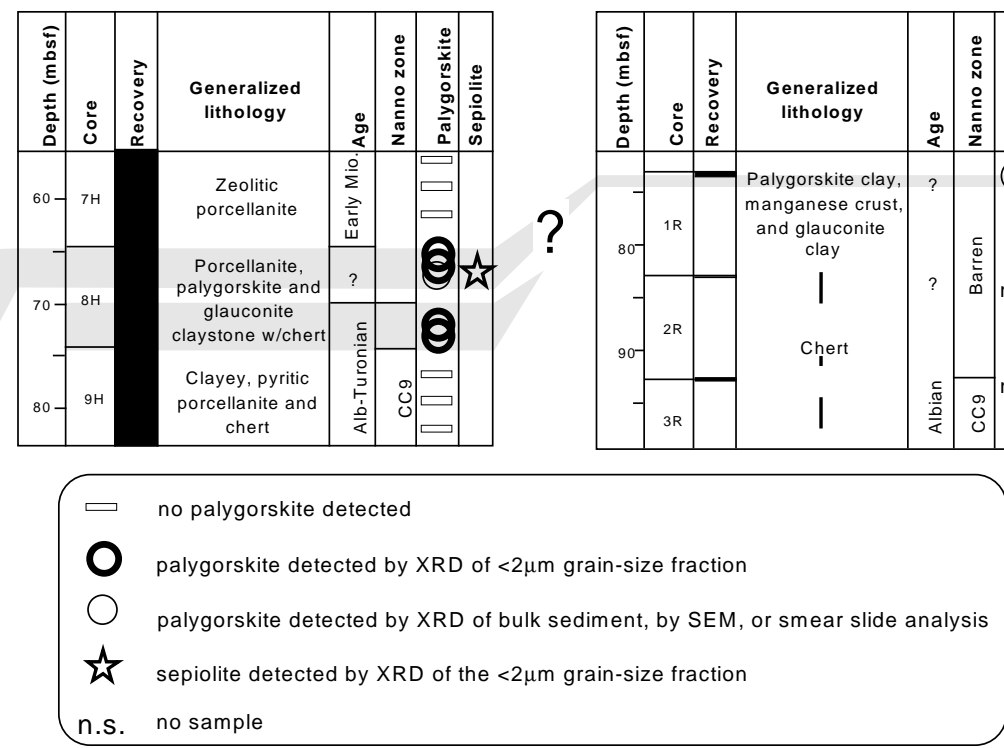

Figure 2. Occurrences of palygorskite as detected by X-ray diffraction of the clay-sized fraction $(<2 \mu \mathrm{m})$ or of the bulk sediment by scanning electron microscopic or light microscopic observation of smear slides. No palygorskite was detected in samples directly above Cores 159-960A-15R and 159-960C-18X or in any samples from the studied holes other than the ones above. Note the variable thickness of the palygorskite-bearing intervals indicated by shading. 
narrower interval, from the top of Core 159-960A-20R to 16R-CC. This interval spans Subzones CP9 through CP10 (Shipboard Scientific Party, 1996d). It is underlain by pieces of Upper Cretaceous calcareous and phosphatic hardgrounds and $70 \mathrm{~cm}$ of undated glauconite clay. The glauconite clay contains abundant limestone and dolostone fragments and calcareous shell and fish debris, including abundant scales. Comparison of diffractograms (Fig. 3) from clay separates of a glaucony-rich (159-960A-21R-1, 26-28 cm) with a glaucony-poor (21R-1, 34-39 cm) interval reveals few qualitative differences. The glaucony-rich sample displays higher intensities for a $7 \AA$ mineral that would conventionally be assigned to kaolinite. However, as documented below, reflections at or around 7.15 $\AA$ and $3.58 \AA$ were only encountered in samples from lithologies with intensely green color or with abundant glaucony grains. The minerals corresponding to these reflections are thought to be odinite or berthierine, two ferriferous, authigenic or early diagenetic clay minerals, rather than kaolinite (Bailey, 1988; Odin et al., 1988).

The first appearance of palygorskite upsection is in Sample 159960A-20R-CC, Paleo-Split, a broken, coarsely crystalline barite nodule. Palygorskite in this sample was observed with the SEM and found to protrude from freshly broken surfaces of the barite crystals (Pl. 2, Figs. 5, 6). Subparallel lenses of palygorskite were apparently overgrown by the coarse-grained barite crystals that constitute the nodule. The first XRD determination upsection is in Sample 159960A-20R-1, 92-94 cm. Palygorskite was detected in two more samples from this core. It occurs in bluish green (5BG 4/1 to 5BG 5/1) clays with intercalated barite nodules and irregular concentrations of barite crystals. Sepiolite was found in two of the three clay fractions analyzed from this core. At the top of Sections 159-960A-20R-1 and 20R-CC, pieces of brownish gray (5Y 5/1) carbonate grainstone occur with some fish debris. Bulk XRD indicates the presence of a dolomitic/ankeritic carbonate besides dominant calcite. The intercalation in this core of sediments with Late Cretaceous and early Eocene ages may result from the reworking of adjacent Cretaceous hardgrounds during the early Eocene or, less probably, from drilling disturbance. There appears to be a hiatus from the latest Cretaceous to the early Eocene.

Four clay separates of samples from Core 159-960A-19R all yielded abundant palygorskite (Fig. 3). Samples from the core catcher are among the purest palygorskite clays encountered on Leg 159, with only minor smectite present. Viewed with the SEM at low magnification, these samples display an open texture of loosely aggregated mats consisting of bundles of subparallel fibers (Pl. 2, Figs. 3, 4). Clays at the bottom of Section 159-960A-19R-1 and in the core catcher are bluish gray (5B 5/1), whereas color gradually shifts to greenish grey $(5 \mathrm{BG} 5 / 1$ to $5 \mathrm{G} 4 / 1)$ toward the top of the core. Two samples from the greenish clay show intense reflections of a $7 \AA$-mineral that are possibly caused by the presence of the green marine clays odinite or berthierine, as in the greenish clay of Hole 960A. The greenish clays display a less porous texture than the bluish clays. The fibrous minerals form a dense web without fraying edges, which covers other mineral grains (Pl. 2, Figs. 1, 2).

Recovery was zero for Core 159-960A-18R and very low in Cores $17 \mathrm{R}$ and $16 \mathrm{R}$, probably because of the presence of chert. Bulk-rock XRD yielded variable, partly very high intensities for palygorskite in samples of the latter two cores. In Core 15R, black porcellanites with zeolite, glauconite, and clay were recovered. The dark color is caused by very high pyrite ( $10 \%$ from a visual estimate) and organic matter contents $(6.4 \mathrm{wt} \%)$. Although the quality of diffractograms from clay separates of this lithology was generally poor, a small peak at $10.5 \AA$, attributed to the presence of palygorskite, appears. Samples from above this core contain smectite, kaolinite and minor illite, but no palygorskite.

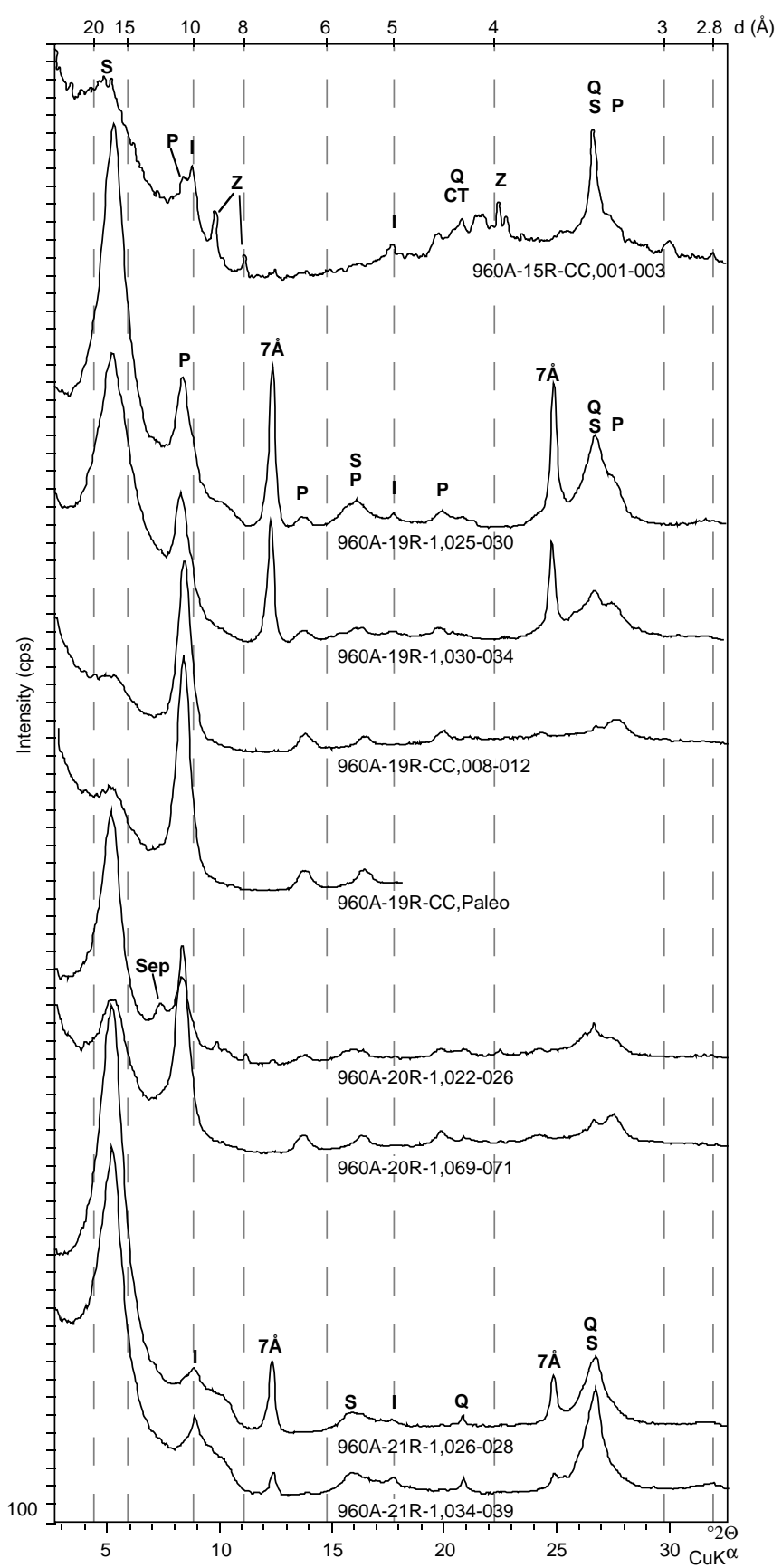

Figure 3. X-ray diffractograms of glycolated clay separates $(<2 \mu \mathrm{m})$ from the palygorskite interval of Hole 960A. $\mathrm{S}=$ smectite, $\mathrm{P}=$ palygorskite, $\mathrm{Sep}=$ Sepiolite, $\mathrm{Z}=$ zeolite (probably clinoptilolite), $\mathrm{I}=$ illite, $\mathrm{Q}=$ quartz, $\mathrm{CT}=$ opal-CT, $7 \AA$ = 7- $\AA$ mineral, probably odinite/berthierine.

\section{Hole 960C}

Hole $960 \mathrm{C}$, which is $\sim 100 \mathrm{~m}$ to the north of $960 \mathrm{~A}$, lies at a present water depth of $2035 \mathrm{~m}$. The base of the palygorskite interval was found at the base of Section 159-960C-23X-1 (198.85 mbsf), but the interval may reach down to $207 \mathrm{mbsf}$. As in Hole 960A, minor palygorskite still occurs $>50 \mathrm{~m}$ above this level in Core 159-960C-18X, 
but palygorskite-rich clays are restricted to a 20-30-m interval between Cores 23X and 21X. The age of this interval falls between Subzones CP9b and CP10. It rests on an Upper Cretaceous brown phosphatic skeletal grainstone with phosphatic fish debris, similar to the sequence of Hole $960 \mathrm{~A}$, but without the glauconite clay at the transition from the carbonates to the palygorskite clays. The absence of this lithology may be a result of the poor recovery.

In Core 159-960C-23X, bluish (5B 5/1) clays are crudely interlaminated with more brownish gray (5Y 4/1) laminae, which contain slightly more organic debris than the bluish laminae. These clays have yielded strongly corroded nannofossils, indicating an early Eocene (CP9b/CP10) age. Irregular accumulations of barite crystals or subspherical barite nodules are intercalated with the clays. No significant change occurs from Cores 159-960C-23X through 21X, except for the occurrence of different siliceous, clayey, carbonate, and baritic lithologies in close contact in Section 22X-CC. SEM observations and EDS measurements of an undisturbed piece of clay with sand-sized barite and dolomite crystals (Sample 159-960C-22X-CC, Paleo-Split) revealed that the interstices between the crystals are filled with coccoliths and fibrous magnesian silicates that are thought to be palygorskite (Pl. 4, Fig. 3). Many crystals and coccoliths are covered with fibers. Curved fibers penetrate the central aperture of coccoliths (Pl. 4, Figs. 4, 5). Silicate strands, possibly also of palygorskite, bridge open joints between barite crystal faces (Pl. 4, Fig. 6). Clay separates of Cores 159-960C-23X through 21X all contain abundant palygorskite, and variable amounts of smectite and sepiolite are present in three out of nine samples (Fig. 4).

Only $10 \mathrm{~cm}$ of chert rubble was recovered in Core 159-960C-20X, and Cores $19 \mathrm{X}$ through $18 \mathrm{X}$ consist of dark brown to very dark grayish brown porcellanites with variable contents of zeolite, carbonate and clay, and high organic carbon content. As in Core 159-960A$15 \mathrm{R}$, the diffractograms of clay separates from this lithology are poor, but two of them display minor peaks at $10.5 \AA$, indicative of palygorskite. Additionally, SEM observation of Sample 159-960C-18X-1, $107-110 \mathrm{~cm}$, has revealed the presence of mineral flakes attached to radiolarian skeletons that are composed of fibrous minerals and curved, spaghetti-like crystals that grow out of the skeletons (Pl. 4, Figs. 1, 2). The skeletons themselves are completely replaced by opal-CT. However, from the electron microscopic evidence alone, it is difficult to determine whether the curved minerals are palygorskite or whether they are a morphological variety of opal-CT similar to the one of nearly the same age described by Thein and von Rad (1987) from the western North Atlantic DSDP Site 605.

\section{Hole 961A}

In Hole 961A, drilled at a present water depth of $3303 \mathrm{~m}$ on the westernmost exposure of the Marginal Ridge, the palygorskite interval lies between 148 and $\sim 170$ mbsf and, except for the very base, falls entirely in calcareous nannofossil Zone CP10 (Shipboard Scientific Party, 1996e). The lithologic context differs from that in Holes 960A and 960C: the palygorskite clay is underlain here by at least 10 $\mathrm{m}$ of middle to upper Paleocene nannofossil porcellanite and glauconitic porcellanite with clay (Core 159-961A-20R and top of 21R) that do not contain palygorskite, but almost pure smectite, in clay separates (Fig. 5). Samples from Core 159-961-19R contain variable but generally minor amounts of palygorskite. Sample 19R-CC, $8-11 \mathrm{~cm}$, a solid piece of light gray, bioturbated sparry nannofossil carbonate with clay and needle-shaped barite crystals, was studied by SEM. Blocky calcite has partly overgrown some of the coccoliths, whereas they are relatively well preserved in the clay-filled interstices between the carbonate crystals (Pl. 3, Fig. 1). Hardly any fibrous minerals can be discerned, although palygorskite has been detected as a minor component in clay separates by XRD. However, flaky silicate minerals, interpreted to be smectite, are attached with their edges to

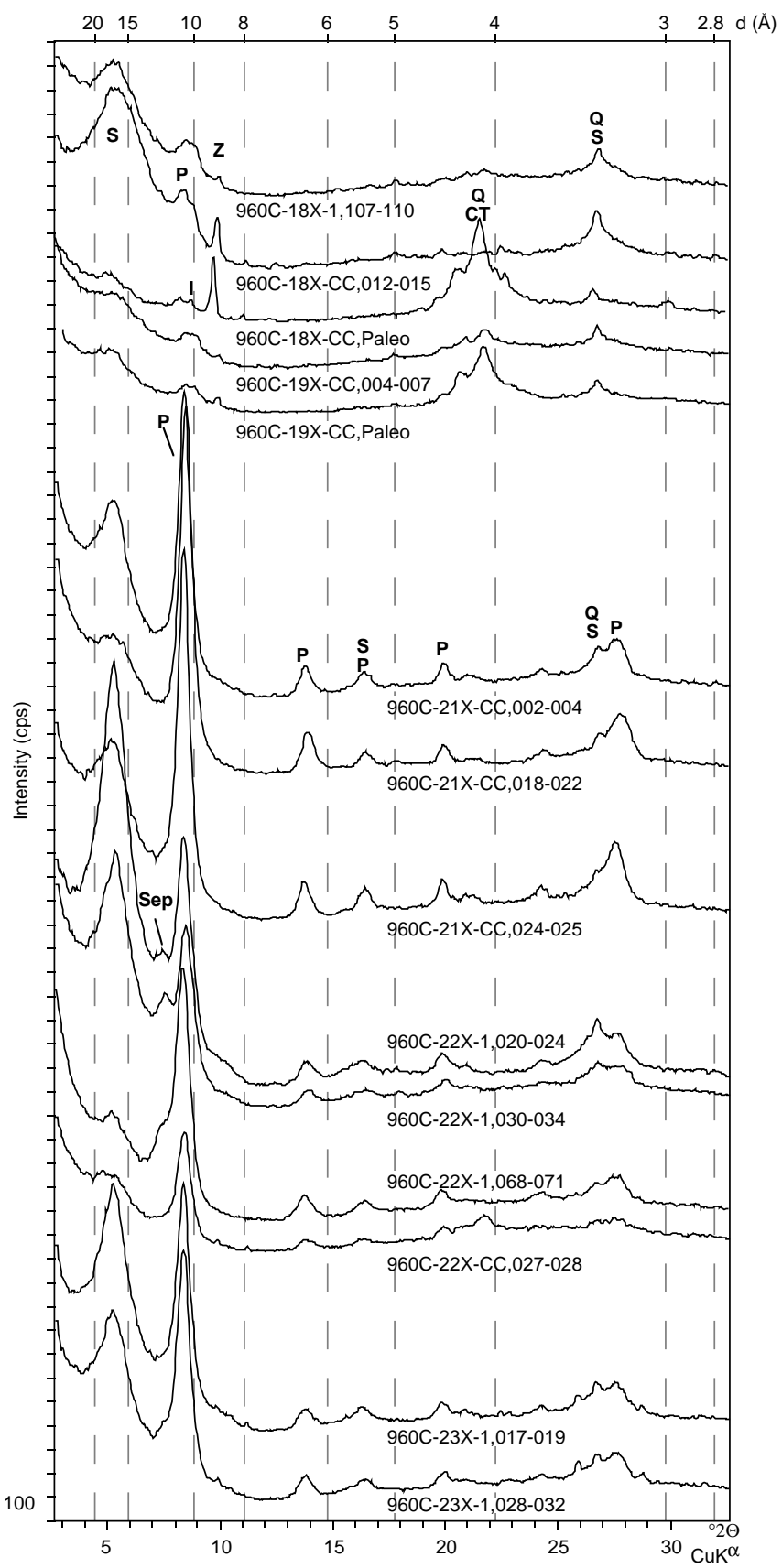

Figure 4. X-ray diffractograms of glycolated clay separates $(<2 \mu \mathrm{m})$ from the palygorskite interval of Hole 960C. See Figure 3 for abbreviations.

the faces of the blocky carbonates (Pl. 3, Fig. 2). This must have happened after the carbonate crystals overgrew the coccoliths.

Palygorskite clay appears upsection in Core 159-961A-18R, containing only $13 \mathrm{~cm}$ of sediment. Clay separates contain abundant palygorskite, smectite, and minor sepiolite. With the SEM at low magnification, a wavy laminated texture is observed (Pl. 1, Fig. 3). Tapering strands and bundles of fibrous minerals rise from the laminae and project into the voids between them (Pl. 1, Fig. 4). Although this latter texture may be an effect of the drying for sample preparation or because of dewatering in the SEM's high vacuum, a look on the laminae or at more massive parts of the samples shows that it is com- 


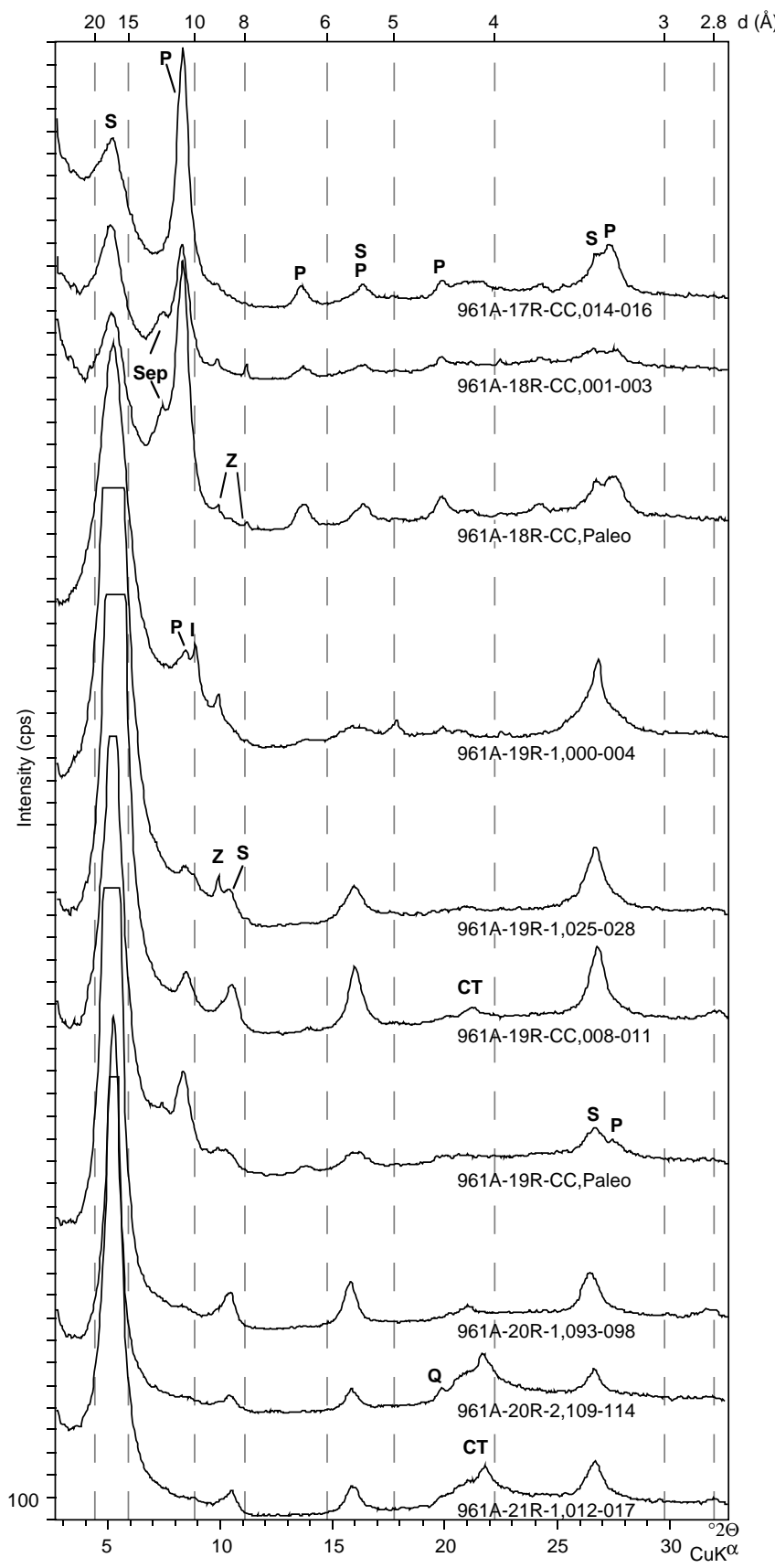

Figure 5. X-ray diffractograms of glycolated clay separates $(<2 \mu \mathrm{m})$ from the palygorskite interval of Hole 961A. See Figure 3 for abbreviations.

pletely constituted of larger flakes made up of interwoven fibers and some smaller, platy minerals (Pl. 1, Fig. 5). The platy minerals often display a pseudo-hexagonal habit reminiscent of well-crystallized kaolinite (Pl. 1, Fig. 6), but only palygorskite, sepiolite, smectite, and some zeolite were detected by XRD in this sample. Although the nature of the platy minerals remains unknown, the fibrous minerals that grow on their faces and edges are thought to be palygorskite or sepiolite, based on the high Mg intensities detected by EDS. Abundant palygorskite also occurs in the clays completely disturbed by drilling between pieces of solid chert in Core 159-961A-17R. It is important to note that Cores $18 \mathrm{R}$ and $17 \mathrm{R}$ both contain abundant, well-pre- served radiolarians and that Cores $20 \mathrm{R}$ and $16 \mathrm{R}$ yielded benthic foraminifers indicative of lower bathyal to abyssal depths for the entire palygorskite interval (Shipboard Scientific Party, 1996e). No palygorskite was found above Core 159-961A-17R.

\section{Hole 962B}

Hole 962B was drilled in $4537 \mathrm{~m}$ of water on the southern margin of an isolated ridge along the strike of the Marginal Ridge. Two distinct palygorskite intervals were encountered in Core 159-962B-8H (Fig. 2). Below this core, Albian-Cenomanian cherts and porcellanites in Core 9H did not yield any palygorskite (Fig. 6). The lower palygorskite interval is of Cenomanian age (Holbourn and Moullade, Chap. 28, this volume) and comprises Sections 8H-5 through 8H-CC. Erbacher (Chap. 29, this volume) found common radiolarian skeletons covered with fibrous minerals in this interval. Caution is needed, however, because these sections are heavily disturbed either by drilling or by sedimentary mixing of chert, glauconitic clay, and palygorskite clay (Shipboard Scientific Party, 1996f). Because of the unknown extent and type of disturbance and the resulting uncertainties in the age determination of the different components of the lower palygorskite interval, it will not be further discussed. However, it is important to note that in the overlying interval with only slightly disturbed Turonian to Santonian glauconitic hardgrounds (beginning with Sample 159-962B-8H-4, 85-86 cm, through Sample 8H-4, 2-4 $\mathrm{cm})$ no palygorskite but only a smectitic mineral and very minor illite were detected. This palygorskite-free interval presumably reaches upsection to Section $8 \mathrm{H}-3,135 \mathrm{~cm}$, where the glauconite hardgrounds are overlain by bluish clay of the upper palygorskite interval.

The upper palygorskite interval comprises Sections 159-962B$8 \mathrm{H}-3$ through $18 \mathrm{H}-1$ and consists of bluish to pale green, mostly laminated, but partly strongly bioturbated clays with zeolite and glauconite pellets. In the richest palygorskite sample from this interval (Sample 159-962B-8H-2, 89-94 cm), SEM observation shows an open texture of larger, composite flakes, made up mostly of curved fibers (Pl. 3, Figs. 3, 4). Palygorskite is less abundant in samples from Sections 159-962B-8H-1 and 8H-3, which were both taken in darker, greenish lithologies. In Sample 8H-3, 100-112 cm, dark green pebbles are abundant. A green pebble of this sample displays higher $\mathrm{Fe}$ readings than the matrix with the SEM in EDX mode. Internally, the pebble displays an open texture of flaky minerals with common edgeto-face contacts (Pl. 3, Figs. 5, 6), which resembles the honeycomb texture of some authigenic clay minerals (Welton, 1984). As in Hole 960A, this $7 \AA$-mineral is probably an authigenic, ferriferous clay mineral (odinite or berthierine).

The upper palygorskite interval, which only yielded abundant shark teeth and undeterminable radiolarians (Erbacher, Chap. 29, this volume), is undated. The underlying sediments are of late Turonian to Santonian age and sediments in Core $159-962 \mathrm{~B}-7 \mathrm{H}$ were dated as lower Miocene, which helps little to bracket its biostratigraphic age. Based on the close lithologic and mineralogic similarity and on the lack of palygorskite in Upper Cretaceous sediments at Sites 959 and 960 , the upper palygorskite interval in Core $8 \mathrm{H}$ is tentatively correlated with the lower Eocene palygorskite clays at the other Leg 159 sites.

\section{Hole 962C}

In Hole 962C, which was drilled $50 \mathrm{~m}$ west of Hole 962B, $14 \mathrm{~cm}$ of bluish palygorskite clay was recovered in Section 159-962C-1R-1 above an irregular piece of black manganese hardground and a siliceous nodule in a matrix of glauconite clay in Section 1R-CC. The age of Core 1R is undetermined. Because of the low amount of material, sampling was restricted to smear slides. The designation as pal- 


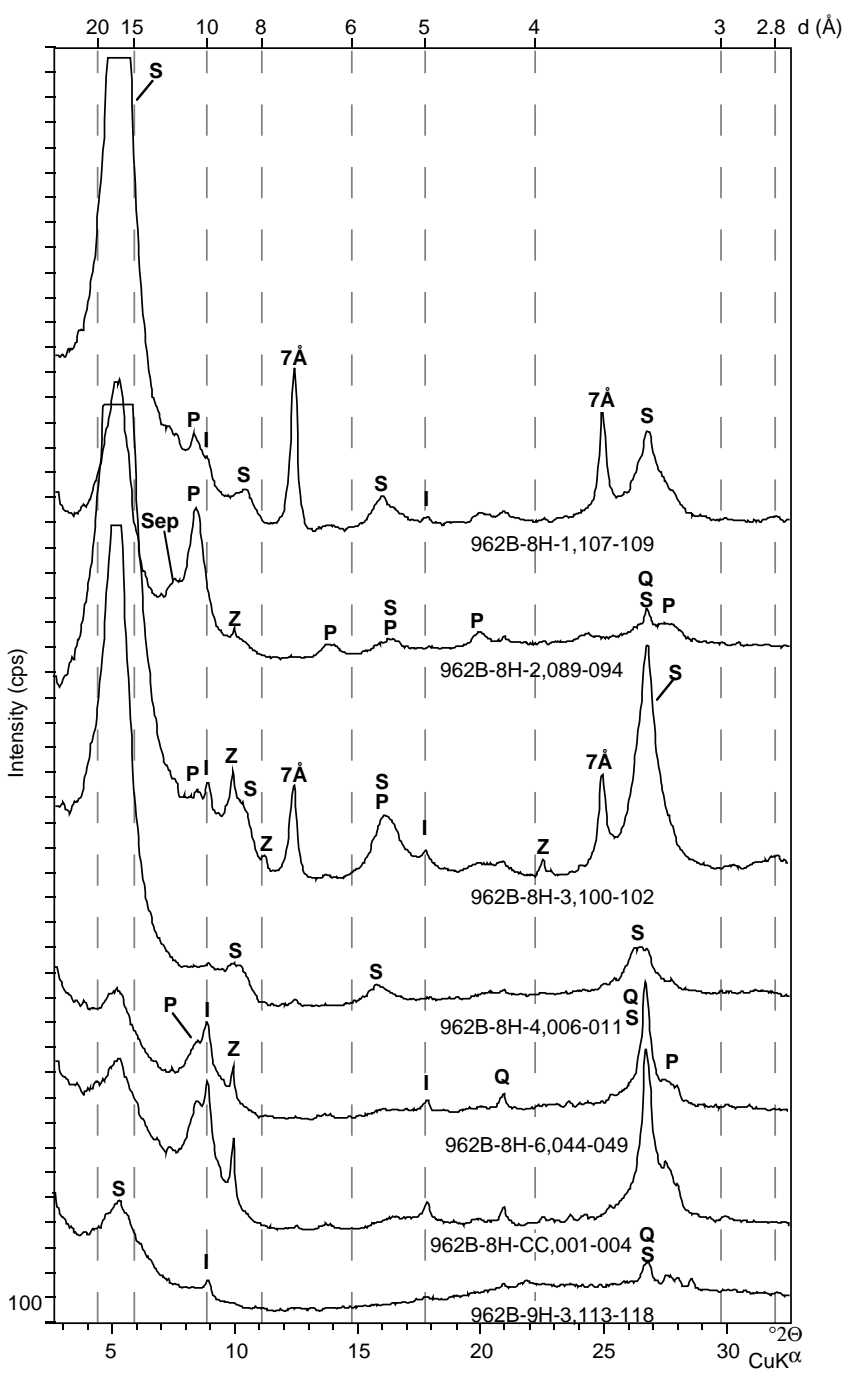

Figure 6. X-ray diffractograms of glycolated clay separates $(<2 \mu \mathrm{m})$ from the palygorskite interval of Hole 962B. See Figure 3 for abbreviations.

ygorskite clay is based on the typical rectangular, netlike extinction pattern of clay aggregates in smear slides and on its bluish color.

\section{ORIGIN OF PALYGORSKITE AT LEG 159}

The conspicuous blue color and the intercalation of the Leg 159 palygorskite clays with coarsely crystalline barite nodules are among the macroscopic features that set these clays apart from common marine sediments. These clays are also remarkable because of the high concentrations of palygorskite compared with many other marine occurrences. In the following discussion, four groups of genetic processes will be evaluated that might explain the occurrence of palygorskite clay at the Leg 159 drill sites:

1. Detrital input from the erosion of authigenic deposits that formed on land or in shallow lagoons;

2. Alteration of pre-existing sediments by diagenetic or hydrothermal fluids;
3. Alteration of pre-existing sediments by lateral flow of saline brines; and

4. Authigenesis at the sediment surface or closely below.

\section{Detrital Input}

It is widely held that deep-marine palygorskite deposits are overwhelmingly detrital and that palygorskite and sepiolite "do not seem to significantly develop in . . . deep-sea deposits" (Chamley, 1989). This view is based on the lack of an actualistic example of marine, authigenic formation, on the common co-occurrence of palygorskite with detrital minerals and on the short crystal forms of palygorskite seen under the transmission electron microscope. In some cases, the occurrence of palygorskite in turbidites and other redeposited sediments and decreasing proportions of palygorskite in a basinward direction have been invoked as further support for its detrital origin (Mélières, 1978; Chamley and Debrabant, 1984; Pletsch et al., 1996; Pletsch, 1997). At other instances, the detrital origin of marine palygorskite is difficult to prove because of the lack of detrital minerals and other sedimentologic evidence for resedimentation, or because the proposed continental or nearshore deposits, where palygorskite should have formed, are eroded, thermally altered, or unknown because of tectonic processes.

As has already been pointed out by Robert and Chamley (1991), there is a discrepancy between the occurrence of palygorskite in $\mathrm{Pa}$ leogene deposits of the marine coastal basins along the Gulf of Guinea and the existence of coeval lateritic, kaolinite-bearing soils or crusts without palygorskite at adjacent terrestrial sites (Millot, 1964, 1970). Robert and Chamley (1991) inferred that palygorskite formation must have taken place in shallow marine lagoons adjacent to these continental areas. In this model, palygorskite would have been eroded from the marginal marine environments and transported to the deep sea (e.g., during times of marine transgression). Several authors have even observed authigenic fabrics in detrital palygorskite aggregates that resulted from reworking of marginal marine palygorskite (Coudé-Gaussen and Blanc, 1985; Daoudi et al., 1995). Although such a model may account for the purity and authigenic texture of the Leg 159 palygorskites, it fails to explain that there is no evidence for detrital palygorskite aggregates of any scale and that sedimentary structures are limited to lamination, and, rarely, to bioturbation. In addition, a nearshore origin of the Leg 159 palygorskites is difficult to reconcile with the observed seaward-increasing thickness of the palygorskite interval in adjacent coastal basins (Skansky, 1958). Direct detrital input of terrestrial palygorskite might have played an important role at other localities, but does not seem to account for its occurrence at the Côte d'Ivoire-Ghana Transform Margin.

Alternatively, palygorskite may have been supplied from arid areas at subtropical latitudes by large scale wind transport, which is effective in the transport of mineral aerosols, including palygorskite, toward the sea (e.g., Tomadin and Lenaz, 1989; Sirocko and Lange, 1991; Fagel et al., 1992). In a recent simulation of late Paleocene climate, the Leg 159 paleoposition would correspond to the boundaries between large-scale areas of strong net precipitation and of strong net evaporation (O'Connell et al., 1996). Hence, tropical rains may have washed out eolian detritus transported either in the southern trade wind belt or via northerly monsoons, at the then very sharp southern boundary of the inner-tropical convergence zone (ITCZ) (O'Connell et al., 1996). However, this scenario does not account for the authigenic texture of the Leg 159 palygorskites and for the virtual absence of detrital minerals in the palygorskite clays.

Electron microscopic observations of Leg 159 palygorskites have shown that this mineral, as independently identified by XRD, often displays an interwoven fabric of fibers that enmesh other particles and of delicate morphologies that can hardly result from depositional 
processes. Minor quartz that was detected in a number of samples probably only reflects its stability in an environment where other minerals were altered. Moreover, quartz is mostly absent from the purest palygorskite clays. Bulk-rock X-ray diffraction analyses often show the highest intensity on the $10.5 \AA$ peak of palygorskite. Such pure clay mineral assemblages typically occur where sedimentary mixing processes have either been overridden by a strongly selective mechanism (i.e., repeated gravitative separation) or where they have been overprinted by subsequent mineral alteration (Chamley, 1989). Thus, very pure clay mineral assemblages are rare in environments that are controlled by erosion and detrital mixing of sedimentary components.

\section{Diagenetic or Hydrothermal Alteration}

As witnessed by the common occurrence of opal-CT, zeolite, and, most strikingly, the barite nodules encountered at Site 960, diagenetic processes have played an important role in the palygorskite intervals. Significant mass transfer through the clays must have taken place to accomplish the formation of the latter, and similar movements of chemical elements leading to palygorskite formation may be envisioned. The common occurrence of palygorskite in close contact with siliceous deposits has led to the hypothesis that the conversion of biogenic opal-A to opal-CT and the concurrent release of $\mathrm{Mg}$ allowed for the diagenetic transformation of smectite or opal itself to palygorskite and sepiolite (e.g., von Rad and Rösch, 1972; Donnelly and Merrill, 1977). However, it is difficult to understand why palygorskite occurs at very different burial depths in lithologies as different as those encountered during Leg 159 , yet usually restricted to a narrow stratigraphic interval, the middle early Eocene. The absence of palygorskite in the $350 \mathrm{~m}$ of Eocene to Oligocene porcellanites and cherts of Site 959 or in the cherts underlying the palygorskite interval in Core 159-962B-8H is not in favor of such an explanation.

Marcano et al. (Chap. 8, this volume) have invoked a possible relationship between the occurrence of barite nodules in the palygorskite intervals and the precipitation of barite vein fills at Sites 959 and 960 from warm formation waters that originated at greater depths. However, the barite nodules found at Sites 960 and 961 bear close similarities to stratiform barite nodules known from hydrothermally unaffected localities. These nodules formed at times of interruptions in sediment accumulation as a result of organic matter decay in the deep ocean or within the upper meters of the sedimentary column (Bréheret and Delamette, 1989; Jewell, 1994). Moreover, SEM observations have clearly shown that the precipitation of nodular barite postdates palygorskite growth (Pl. 2, Figs. 5, 6).

Bowles et al. (1971), Bonté et al. (1980), Bonatti et al. (1982), Karpoff et al. (1989), and Gibbs et al. (1993) studied relatively pure palygorskites and sepiolites that were recovered in the proximity of ultramafic basement ridges, active spreading ridges, or oceanic fracture zones. These authors interpreted the occurrence of fibrous clays to be a result of direct precipitation from hydrothermal solutions that interacted with seawater or from seawater that had leached $\mathrm{Mg}$ and $\mathrm{Si}$ from basalt, or from the alteration of ultramafic rocks. Because the Côte d'Ivoire-Ghana Transform Margin is the prolongation of the Romanche Fracture Zone, a similar origin of palygorskite and sepiolite at these sites may be suspected. In all of the above cases, however, the fibrous clays were found to be in immediate contact with either basaltic or ultramafic basement, disseminated in volcanogenic sediments rich in feldspar and pyroxene, or in veins made up exclusively of palygorskite. No such lithologic association and no palygorskite veins were found at the Leg 159 drill sites. The closest occurrence of oceanic basement is located downslope from Site 962, which, however, displays a relatively thin palygorskite interval. The thickest in- tervals with the purest palygorskite clay were found at Sites 960 and 961 that are clearly located on continental basement (Mascle, Lohmann, Clift, et al., 1996). Because of the presence of some well-preserved radiolarians, or minerals like opal-CT and possibly odinite/ berthierine, which would not have survived temperatures higher than $60^{\circ}-80^{\circ} \mathrm{C}$ (Riech and von Rad, 1979a, 1979b; Hornibrook and Longstaffe, 1996), elevated burial temperatures or hydrothermal flow through the palygorskite clays are unlikely.

\section{Alteration by Lateral Flow of Salt Brines}

It has been proposed, on the base of the co-occurrence in the same depth intervals along the West African margin of palygorskite and of increased magnesium concentration and salinity, that this mineral formed as a result of continuous precipitation of ion-enriched brines (Gieskes, 1981). Considerable evidence points to the possibility that these brines originated on the continents, then moved down the continental slope, where they passed the salt domes of this area and took up salinity before they precipitated some of their dissolved load in the porous sediments (sandstone, porcellanite) where palygorskite was found (e.g., Couture et al, 1978; Gieskes et al., 1980). In fact, traces of palygorskite were found in the porous porcellanites immediately overlying the palygorskite clays at Site 960. However, authigenic fabrics found within the palygorskite clays are pervasive and are not restricted to interstices or specific horizons, as would be expected if precipitation would take place in a confined aquifer. Instead, porosity displays distinct minima in the palygorskite intervals at Sites 959 and 960 (Shipboard Scientific Party, 1996c, 1996d). Although porosity of the latter lithologies was certainly higher before compaction or alteration, it is difficult to understand why there is no or very little palygorskite in the sediments above and below these intervals that retain very high porosities until the present. Moreover, no evidence was found for salt accumulations along the Côte d'Ivoire-Ghana Transform Margin, and decreases rather than increases in salinity and $\mathrm{Mg}$ concentrations were observed at the depths where palygorskite occurs during Leg 159 (Mascle, Lohmann, Clift, et al., 1996).

\section{Authigenic Growth Close to the Sediment Surface}

Contrary to the "detrital palygorskite" model of Chamley, Weaver, and others, several authors proposed that palygorskite formation is feasible at the deep seafloor (Millot, 1964, 1970; Couture, 1977; Kastner, 1981; Karpoff et al., 1989; Thiry and Jacquin, 1993). These authors cited among the factors that would favor palygorskite growth increased input of $\mathrm{Mg}$ and $\mathrm{Si}$-ions (probably from weathering solutions), low Al-activities, higher ambient temperatures, an alkaline $\mathrm{pH}$, and prolonged residence times of minerals at the sediment/seawater interface.

Actualistic models may not be appropriate to explain palygorskite occurrence prior to the Neogene: Palygorskite is found much more frequently in mid-Cretaceous to early Cenozoic than in younger deposits. Peak abundances are in marine sediments of the Late Cretaceous and Eocene (Kastner, 1981; Callen, 1984). Except for the lower palygorskite interval in Core 159-962B-8H that is of a Late Cretaceous (Cenomanian) age, the palygorskite clays of Leg 159 are confined to the middle early Eocene (mostly calcareous nannofossil Subzone CP10). This restriction of palygorskite to a narrow stratigraphic interval points toward a process that was limited to the same time period. As shown above, detrital, hydrothermal, or late diagenetic processes do not account for the mineralogical and textural characteristics of the palygorskite clays. However, the higher water temperatures and increased ion-content that are required for palygorskite formation were very probably realized in the early Eocene tropical oceans. The major occurrences of palygorskite in space and time co- 
incide with both the episodes and the areas that were proposed for the production of late Paleocene warm, saline deep water (e.g., O'Connell et al., 1996). It is thus speculated that the reason for the formation of warm, saline deep waters may have been the same as for the formation of marine authigenic palygorskite (i.e., well-developed zones of strong net-evaporation). The evaporative conditions were potentially responsible for the production of warm brines in the extended shallow seas that were able to travel down the continental slopes to form the intermediate and/or deep waters as a result of their salinityreduced buoyancy (Brass et al., 1982; Busson, 1984). If it is assumed that the physico-chemical conditions of hypersaline lagoons have periodically or continuously expanded toward the open sea and eventually reached the deep seafloor, then the hypothesis of transformation of pre-existing minerals to palygorskite at the seafloor is viable.

Although the transformation of another mineral to palygorskite itself has not been proven, there is little doubt that the palygorskite clays of Leg 159 formed close to the Eocene deep seafloor after deposition of the sediment. Similarly, there is no direct evidence for the formation of the studied authigenic palygorskite through alteration of pre-existing minerals by warm-saline deep waters at the present time. However, from the physico-chemical prerequisites cited above and in the absence of another plausible genetic mechanism, it is thought that the authigenic palygorskite found at the Leg 159 drill sites formed by transformation of smectites or other clay minerals in the presence of excess silica, magnesium, and alkalinity. These waters were probably supplied by the same brines that constituted the warm, saline deeper waters proposed for the early Eocene ocean (Kennett and Stott, 1990).

\section{CONCLUSIONS}

Lower Eocene palygorskite clays of Leg 159 are thought to have formed through an as yet unknown, early postdepositional process close to the deep seafloor. This assumption is based on the authigenic texture of palygorskite clays in the electron microscope, on their mineralogical purity, on the lack of indications for reworking, hydrothermalism or burial diagenetic phenomena, and on the coeval occurrence of autochthonous bathyal to abyssal benthic foraminifer assemblages. In the early Eocene, palygorskite was a common component of marine clays deposited in tropical and subtropical latitudes. It is speculated that elevated deep-water temperatures, $\mathrm{Mg}$ - and Si-activities, reduced terrigenous input, and a presumably higher alkalinity of the early Eocene oceanic deeper waters led to the transformation of pre-existing clay minerals to palygorskite at the sediment/seawater interface or closely below. Abundance of authigenic palygorskite in the early Eocene at Leg 159 indicates the position of well-developed zones of net evaporation over the equatorial Atlantic and probably corresponds to phases when oceanic circulation was driven by warm, saline deep waters produced in low-latitude seas.

\section{ACKNOWLEDGMENTS}

Participation in Leg 159 and shore-based research was funded by the German Research Council (DFG) project Ku 649/2. I am grateful to the ODP, Sedco and Catermar staffs, who made Leg 159 a successful and pleasant cruise. Shore-based sampling was realized with the assistance of W. Hale and A. Wülbers. XRD analyses were performed at Laboratoire de Géodynamique et Sédimentologie, Univ. de Lille, France, with the patient help of P. Recourt, P. Vanderaveroet, D. Malengros, and N. Pernot. M.A. Cusimano put much effort into our shipboard XRD analyses. Technical help by A. Kirch, U.
Schmölke, A. Frantz, W. Reimann, and U. Schuldt is gratefully acknowledged. Various aspects of this paper have benefited from discussions with J.-F. Deconinck, J. Erbacher, M.A. Holmes, W. Kuhnt, R.D. Norris, R. Petschick, and C. Samtleben. A.E.L. Holbourn and F. Stengele critically read earlier versions of the manuscript. J. Gieskes, M. Moullade, and C. Robert reviewed the manuscript and made many valuable suggestions.

\section{REFERENCES}

Bailey, S.W., 1980. Structures of layer silicates. In Brindley, G.W., and Brown, G. (Eds.), Crystal Structures of Clay Minerals and Their X-ray Identification. Mineral. Soc. London Monogr., 5:1-124.

, 1988. Structures and compositions of other trioctahedral 1:1 phyllosilicates. In Bailey, S.W. (Ed.), Hydrous Phyllosilicates (Exclusive of Micas). Rev. Mineral., 19:169-188.

Berger, W.H., and von Rad, U., 1972. Cretaceous and Cenozoic sediments from the Atlantic Ocean. In Hayes, D.E., Pimm, A.C., et al., Init. Repts. DSDP, 14: Washington (U.S. Govt. Printing Office), 787-954.

Bonatti, E., and Joensuu, O., 1968. Palygorskite from Atlantic deep-sea sediments. Am. Mineral., 53:925-983.

Bonatti, E., Simmons, E.C., Berger, D., Hamlyn, P.R., and Lawrence, L., 1982. Ultramafic rock/seawater interaction in the oceanic crust. Mg-silicate (sepiolite) deposit from the Indian Ocean floor. Earth Planet. Sci. Lett., 62:229-238.

Bonté, P., Lalou, C., and Latouche, C., 1980. Ferromanganese deposits in cores from the Kane and Atlantis fracture areas: possible relationships with hydrothermalism. J. Geol. Soc. London, 137:373-377.

Bowles, F.A., Angino, E.A., Hosterman, J.W., and Galle, O.K., 1971. Precipitation of deep-sea palygorskite and sepiolite. Earth Planet. Sci. Lett., 11:415-432.

Brass, G.W., Southam, J.R., and Peterson, W.H., 1982. Warm saline bottomwater in the ancient ocean. Nature, 296:620-623.

Bréheret, J.-G., and Delamette, M., 1989. Les nodules barytiques d'age Crétacé moyen dans le domaine Vocontien (SE-France), marqueurs de discontinuitiés sédimentaires en série marneuse de bassin. $C$. R. Acad. Sci. Paris 2, 308:1369-1374.

Brindley, G.W. and Brown, G., (Eds.), 1980. Crystal Structures of Clay Minerals and their X-Ray Identification. London, Mineral. Soc. Mono., (Vol. $5)$.

Busson, G., 1984. Relations entre la sédimentation du Crétacé moyen et supérieur de la plate-forme du nord-ouest africain et les dépôts contemporains de l'Atlantique centre et nord. Eclogae Geol. Helv., 77:221-235.

Callen, R.A., 1984. Clays of the palygorskite-sepiolite group: depositional environment, age and distribution. In Singer, A., and Galán, E. (Eds.), Palygorskite-Sepiolite: Occurrence, Genesis and Uses: Amsterdam (Elsevier), Devl. in Sedimentol., 37:1-37.

Chamley, H., 1989. Clay Sedimentology: Berlin (Springer-Verlag).

Chamley, H. and Debrabant, P., 1984. Mineralogical and geochemical investigations of sediments on the Mazagan Plateau, northwestern African margin (Leg 79, Deep Sea Drilling Project). In Hinz, K., Winterer, E.L., et al., Init. Repts. DSDP, 79: Washington (U.S. Govt. Printing Office), 497-508.

Chamley, H., Diester-Haass, L., and Lange, H., 1977. Terrigenous material in East Atlantic sediment cores as an indicator of NW African climates. "Meteor" Forschungsergeb. Reihe C, 26:44-59.

Church, T.M., and Velde, B., 1979. Geochemistry and origin of a deep-sea Pacific palygorskite deposit. Chem. Geol., 25:31-39.

Corfield, R.M., 1994. Palaeocene oceans and climate: an isotope perspective. Earth-Sci. Rev., 37:225-252

Coudé-Gaussen, G., and Blanc, P., 1985. Présence de grains éolisés de palygorskite dans les poussiéres actuelles et les sédiments d'origine désertique. Bull. Soc. Geol. Fr., 4:571-579.

Couture, R.A., 1977. Composition and origin of palygorskite-rich and montmorillonite-rich zeolite-containing sediments from the Pacific Ocean. Chem. Geol., 19:113-130.

, 1978. Miocene of the S.E. United States: a model for chemical sedimentation in a peri-marine environment: comments. Sediment. Geol., 21:149-157. 
Couture, R.A., Miller, R.S., and Gieskes, J.M., 1978. Interstitial water and mineralogical studies, Leg 41. In Lancelot, Y., Seibold, E., et al., Init. Repts. DSDP, 41: Washington (U.S. Govt. Printing Office), 907-914.

Daoudi, L., Charroud, M., Deconinck, J.F., and Bouabdelli, M., 1995. Distribution et origine des minéraux argileux des formations Crétacé-Éocene du Moyen Atlas sud-occidental (Maroc): signification paléogéographique. Ann. Soc. Geol. Nord, 4:31-40.

Donnelly, T.W., and Merrill, L., 1977. The scavenging of magnesium and other chemical species by biogenic opal in deep-sea sediments. Chem. Geol., 19:167-186.

Fagel, N., Debrabant, P., de Menocal, P., and Demoulin, B., 1992. Utilisation des minéraux sédimentaires argileux pour la reconstruction des variations paléoclimatiques à court terme en Mer d'Arabie. Oceanol. Acta, 15:125136

Gibbs, A.E., Hein, J.R., Lewis, S.D., and McCulloch, D.S., 1993. Hydrothermal palygorskite and ferromanganese mineralization at a central California margin fracture zone. Mar. Geol., 115:47-65.

Gieskes, J.M., 1981. Deep-sea drilling interstitial water studies: implications for chemical alteration of the oceanic crust, layers I and II. In Warme, J.E., Douglas, R.G., and Winterer, E.L. (Eds.), The Deep Sea Drilling Project: A Decade of Progress. Spec. Publ.-Econ. Paleontol. Mineral., 32:149-167

Gieskes, J.M., Graham, D., and Ellis, R. 1980. Interstitial-water studies, Deep Sea Drilling Project Sites 415 and 416. In Lancelot, Y., Winterer, E.L., et al., Init. Repts. DSDP, 50: Washington (U.S. Govt. Printing Office), 691-693.

Greenwood, D.R., and Wing, S.L., 1995. Eocene continental climates and latitudinal temperature gradients. Geology, 23:1044-1048.

Hartmann, M., Lange, H., Seibold, E., and Walger, E., 1971. OberflächenSedimente im Persischen Golf von Oman, I. Geologisch-hydrologischer Rahmen und erste sedimentologische Ergebnisse. "Meteor" Forschungsergeb. Reihe C, 100:1-76.

Holtzapffel, T., 1985. Les minéraux argileux: préparation, analyse diffractométrique et détermination. Publ. Soc. Geol. Nord., 12.

Hornibrook, E.R.C., and Longstaffe, F.J., 1996. Berthierine from the Lower Cretaceous Clearwater formation, Alberta, Canada. Clays Clay Miner, $44: 1-21$.

Jewell, P.W., 1994. Paleoredox conditions and the origin of bedded barites along the Late Devonian North American continental margin. J. Geol., 102:151-164.

Jones, B.F., and Galán. E., 1988. Sepiolite and palygorskite. In Bailey, S.W. (Ed.), Hydrous Phyllosilicates (Exclusive of Micas). Rev. Mineral., 19:631-674.

Karpoff, A.M., Lagabrielle, Y., Boillot, G., and Girardeau, J., 1989. L'authigenèse océanique de palygorskite par halmyrolyse de péridotites serpentinisées (Marge de Galice): ses implications géodynamiques. C. R. Acad. Sci. Ser. 2, 308:647-654.

Kastner, M., 1981. Authigenic silicates in deep sea sediments: formation and diagenesis. In Emiliani, C. (Ed.), The Sea (Vol. 7): The Oceanic Lithosphere: New York (Wiley), 915-980.

Kennett, J.P., and Stott, L.D., 1990. Proteus and Proto-oceanus: ancestral Paleogene oceans as revealed from Antarctic stable isotopic results: ODP Leg 113. In Barker, P.F., Kennett, J.P., et al., Proc. ODP, Sci. Results, 113: College Station, TX (Ocean Drilling Program), 865-880.

Lange, H., 1975. Herkunft und Verteilung von Oberflächensedimenten des westafrikanischen Schelfs und Kontinentalhanges. "Meteor" Forschungsergeb. C, 22:61-84.

López-Galindo, A., Torres-Ruíz, J., and González-López, J.M., 1996. Mineral quantification in sepiolite-palygorskite deposits using X-ray diffraction and chemical data. Clay Miner., 31:217-224.

Mascle, J., Lohmann, G.P., Clift, P.D., et al., 1996. Proc. ODP, Init. Repts., 159: College Station, TX (Ocean Drilling Program).

Mélières, F., 1978. X-ray mineralogy studies, Leg 41, Deep Sea Drilling Project, eastern North Atlantic Ocean. In Lancelot, Y., Seibold, E., et al., Init. Repts. DSDP, 41: Washington (U.S. Govt. Printing Office), 10651086.

Millot, G., 1964. Géologie des Argiles: Paris (Masson). 1970. Geology of Clays: Berlin (Springer).

Moore, D.M. and Reynolds, R.C., Jr., 1989. Qauntitative Analysis. In Moore, D.M., and Reynolds, R.C., Jr., (Eds.), X-ray Diffraction and the Identification and Analysis of Clay Minerals: Oxford, (Oxford University Press), 272-309.
Natland, J.H., and Mahoney, J.J., 1982. Alteration in igneous rocks at DSDP sites 458 and 459, Mariana fore arc region relationship to basement structures. In Hussong, D.M., Uyeda, S., et al., Init. Repts. DSDP, 60: Washington (U.S. Govt. Printing Office), 769-788.

O'Connell, S., Chandler, M.A., and Ruedy, R., 1996. Implications for the creation of warm saline deep water: Late Paleogene reconstructions and global climate model simulations. Geol. Soc. Am. Bull., 108:270-284.

Odin, G.S., Knox, R.W.O., Gygi, R.A., and Guerrak, S., 1988. Green marine clays from the oolitic ironstone facies: habit, mineralogy, environment. In Odin, G.S. (Ed.), Green Marine Clays: Amsterdam (Elsevier), Devl. in Sedimentol., 45:29-52.

Paquet, H., 1970. Evolution géochimique des minéraux argileux dans les altérations et les sols des climats méditerranéens et tropicaux à saisons contrastées. Mem. Serv. Carte Geol. Als.-Lorr., 30:1-212.

Pletsch, T., 1997. Clay minerals in Cretaceous deep-water formations of the Rif and the Betic Cordillera (northern Morocco \& southern Spain). Soc. Géol. Nord, Publ., 26: 1-106.

Pletsch, T., Daoudi, L., Chamley, H., Deconinck, J.F., and Charroud, M., 1996. Palaeogeographic controls on palygorskite occurrence in mid-Cretaceous sediments of Morocco and adjacent basins. Clay Miner., 31:403416.

Railsback, L.B., Anderson, T.F., Ackerly, S.C., and Cisne, J.L., 1989. Paleoceanographic modeling of temperature-salinity profiles from stable isotopic data. Paleoceanography, 4:585-591.

Riech, V., and von Rad, U., 1979. Eocene porcellanites and Early Cretaceous cherts from the Western North Atlantic basin. In Tucholke, B.E., Vogt, P.R., et al., Init. Repts. DSDP, 43: Washington (U.S. Govt. Printing Office), 437-448.

, 1979. Silica diagenesis in the Atlantic Ocean: diagenetic potential and transformations. In Talwani, M., Hay, W., and Ryan, W.B.F. (Eds.), Deep Drilling Results in the Atlantic Ocean: Continental Margins and Paleoenvironment. Am. Geophys. Union, Maurice Ewing Ser., 3:315340.

Robert, C., and Chamley, H., 1991. Development of early Eocene warm climates, as inferred from clay mineral variations in oceanic sediments. Palaeogeogr., Palaeoclimatol., Palaeoecol., 89:315-331.

Shipboard Scientific Party, 1996a. Explanatory notes. In Mascle, J., Lohmann, G.P., Clift, P.D., et al., Proc. ODP, Init. Repts., 159: College Station, TX (Ocean Drilling Program), 17-46.

1996b. Principal results. In Mascle, J., Lohmann, G.P., Clift, P.D., et al., Proc. ODP, Init. Repts., 159: College Station, TX (Ocean Drilling Program), 297-314.

, 1996c. Site 959. In Mascle, J., Lohmann, G.P., Clift, P.D., et al., Proc. ODP, Init. Repts., 159: College Station, TX (Ocean Drilling Program), 65-150.

, 1996d. Site 960. In Mascle, J., Lohmann, G.P., Clift, P.D., et al., Proc. ODP, Init. Repts., 159: College Station, TX (Ocean Drilling Program), 151-215.

1996e. Site 961. In Mascle, J., Lohmann, G.P., Clift, P.D. et al., (Eds.), Proc. ODP, Init. Repts., 159: College Station, TX (Ocean Drilling Program), 217-249.

1996f. Site 962. In Mascle, J., Lohmann, G.P., Clift, P.D., et al., Proc. ODP, Init. Repts., 159: College Station, TX (Ocean Drilling Program), 251-294.

Singer, A., 1979. Palygorskite in sediments: detrital, diagenetic or neoformed: a critical review. Geol. Rundsch., 68:996-1008.

, 1984. The paleoclimatic interpretation of clay minerals in sediments: a review. Earth-Sci. Rev., 21:251-293.

1989. Palygorskite and sepiolite group minerals. In Minerals in Soil Environments (2nd ed.): Soil Sci. Soc. Am., SSSA Book Ser., 1:9961008.

Sirocko, F., and Lange, H., 1991. Clay-mineral accumulation in the Arabian Sea during the late Quaternary. Mar. Geol., 97:105-119.

Skansky, M., 1958. Vue d'ensemble sur le bassin sédimentaire cotier du Dahomey-Togo. Bull. Soc. Geol. Fr., 8:555-580.

Skansky, M., Camez, T., and Millt, G., 1959. Sédimentation arguleuse et phosphate au Dahomey. Bull. Soc. Géol. Fr., 1:150-155.

Stengele, F., 1997. Mineralogische Untersuchungen an mesozoischen und quartären Tonen und Evaporiten Südosttunesiens. [Ph.D. dissert.], Univ. Karlsruhe, Germany.

Thein, J., and von Rad, U., 1987. Silica diagenesis in continental rise and slope sediments off eastern North America (Sites 603 and 605, Leg 93; 
Sites 612 and 614, Leg 95). In Poag, C.W., Watts, A.B., et al., Init. Repts. DSDP, 95: Washington (U.S. Govt. Printing Office), 501-525.

Thiry, M., and Jacquin, T., 1993. Clay mineral distribution related to rift activity, sea-level changes and paleoceanography in the Cretaceous of the Atlantic Ocean. Clay Miner., 28:61-84.

Tomadin, L., and Lenaz, R., 1989. Eolian dust over the Mediterranean and their contribution to the present sedimentation. In Leinen, M., and Sarnthein, M. (Eds.), Paleoclimatology and Paleometeorology: Modern and Past Patterns of Global Atmospheric Transport. NATO ASI Ser., 282:267-282.

von Rad, U., and Rösch, H., 1972. Mineralogy and origin of clay minerals, silica and authigenic silicates in Leg 14 sediments. In Hayes, D.E., Pimm, A.C., et al., Init. Repts. DSDP, 14: Washington (U.S. Govt. Printing Office), 727-746.

Weaver, C.E., 1989. Clays, Muds, and Shales: New York (Elsevier), Dev. in Sedimentol. Ser., 44.
Weaver, C.E., and Beck, K.C., 1977. Miocene of the S.E. United States: a model for chemical sedimentation in a peri-marine environment. Sediment. Geol., 17:1-234.

Welton, J.E., 1984. SEM Petrology Atlas.AAPG, Methods Expl. Ser

Zachos, J.C., Lohmann, K.C., Walker, J.C.G., and Wise, S.W., Jr., 1993. Abrupt climate change and transient climates during the Paleogene: a marine perspective. J. Geol., 101:191-213.

Zachos, J.C., Stott, L.D., and Lohmann, K.C., 1994. Evolution of early Cenozoic marine temperatures. Paleoceanography, 9:353-387.

Date of initial receipt: 20 September 1996

Date of acceptance: 1 April 1997

Ms 159SR-012 

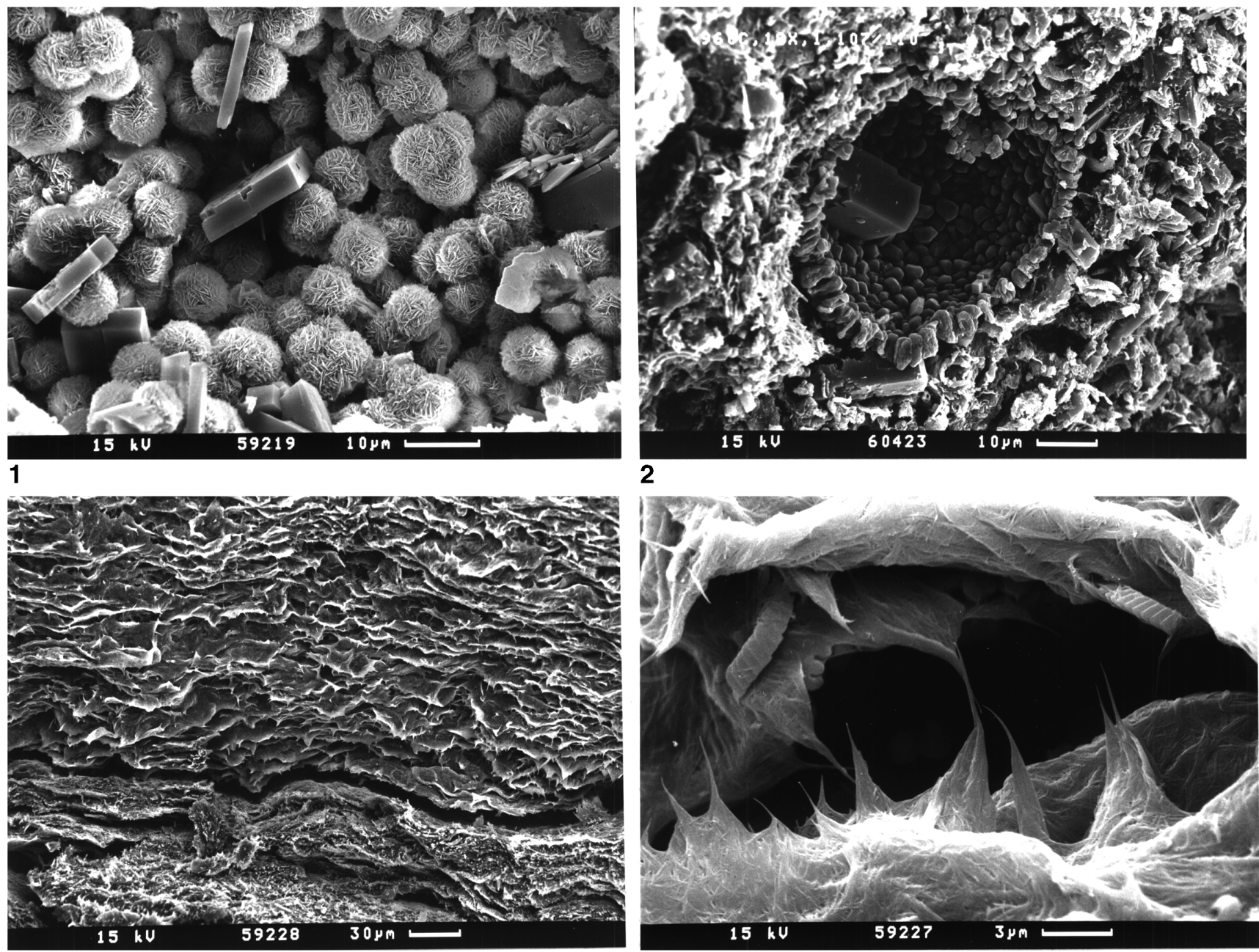

3

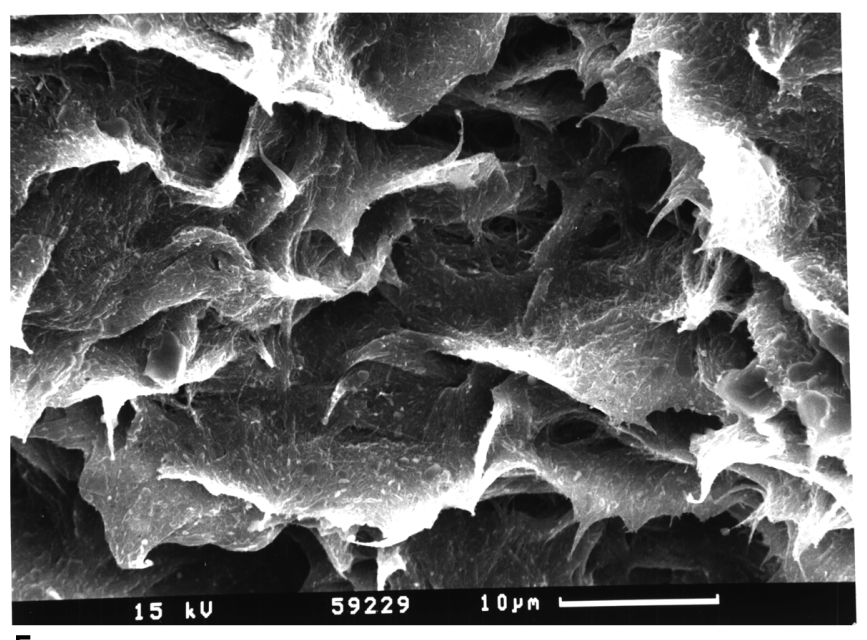

4

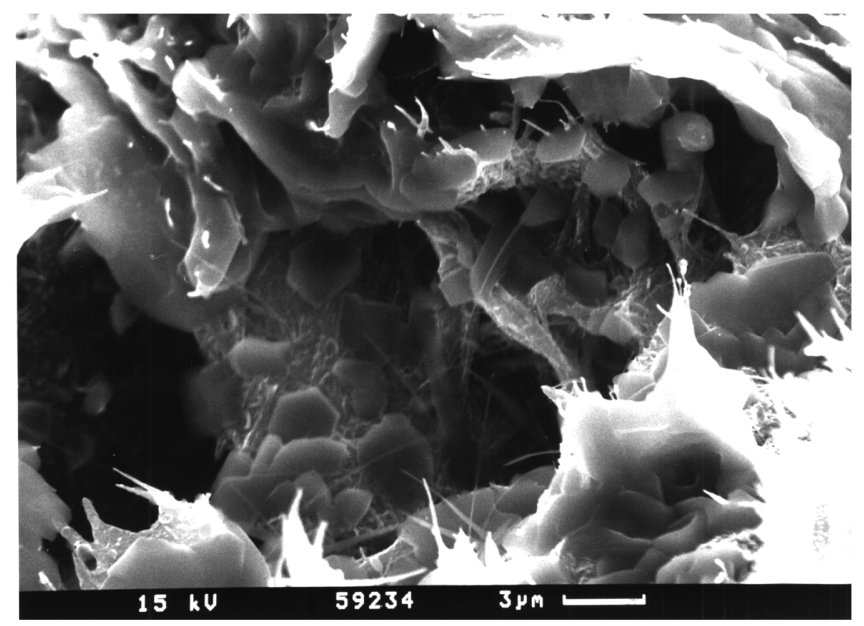

6

Plate 1. Scanning electron micrographs. 1. Sample 159-961A-17R-CC, Paleo-Split, from the top of the palygorskite-bearing interval, almost entirely consists of opal-CT lepispheres and euhedral zeolite crystals. Clay was found to cover some lepispheres (middle right). Calcareous nannofossils and spherical tests (calcispheres?) also occur. 2. Sample 159-960C-18X-1, 107-110 cm. Lithology similar to 1. Spherical test (calcisphere?) with euhedral zeolite crystal inside. Matrix consists of opal-CT lepispheres covered with flaky clay aggregates, calcareous nannofossils, and zeolite crystals. 3. Sample 159-961A-18R-CC, Paleo-Split, palygorskite clay with calcareous nannofossils displays wavy, laminated texture. 4. Detail of 3. Open texture with fine, tapering bundles of palygorskite fibers may be an artifact of drying during sample preparation or of the SEM's vacuum. 5. Detail of 3. Larger flakes consist of interwoven fibers and platy minerals. 6. Detail of 3. Platy minerals often show pseudo-hexagonal outlines reminiscent of well-crystallized kaolinite. Fibrous minerals grow from the edges and faces of the platy minerals. Note that only palygorskite, sepiolite, smectite, and zeolite were detected in clay separates by XRD (see Fig. 5). 

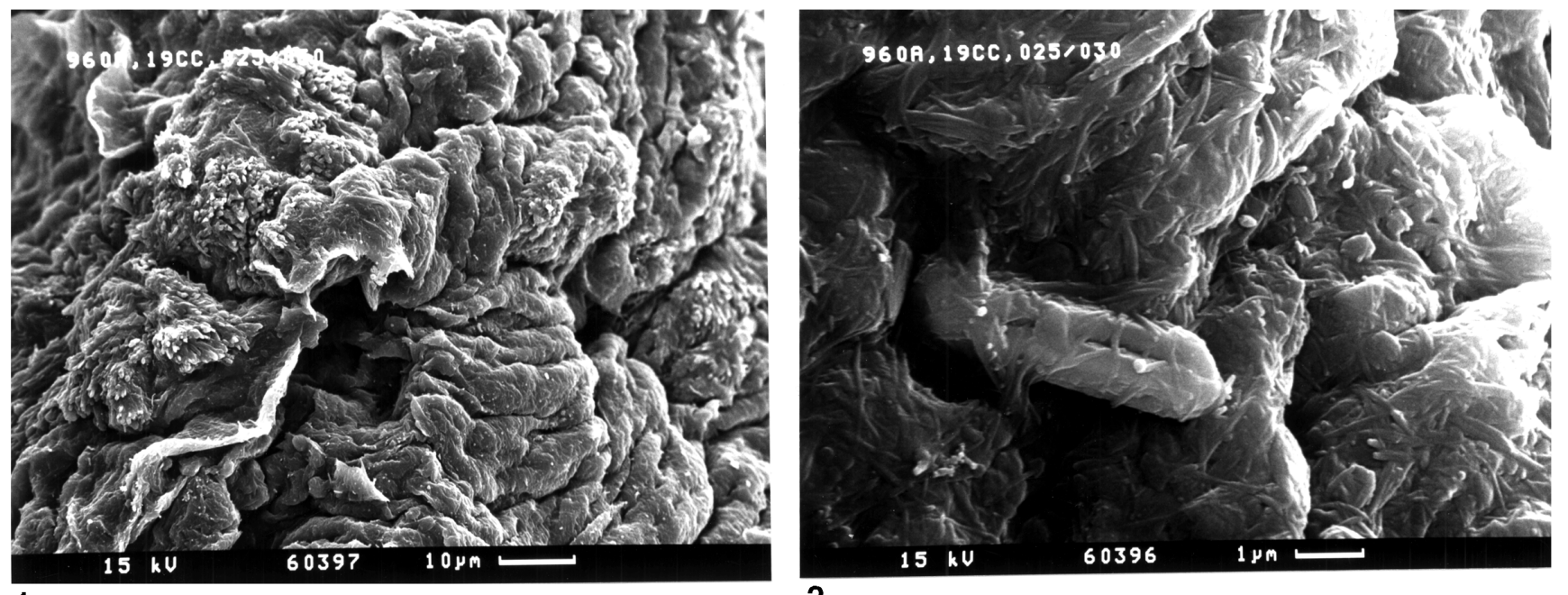

1

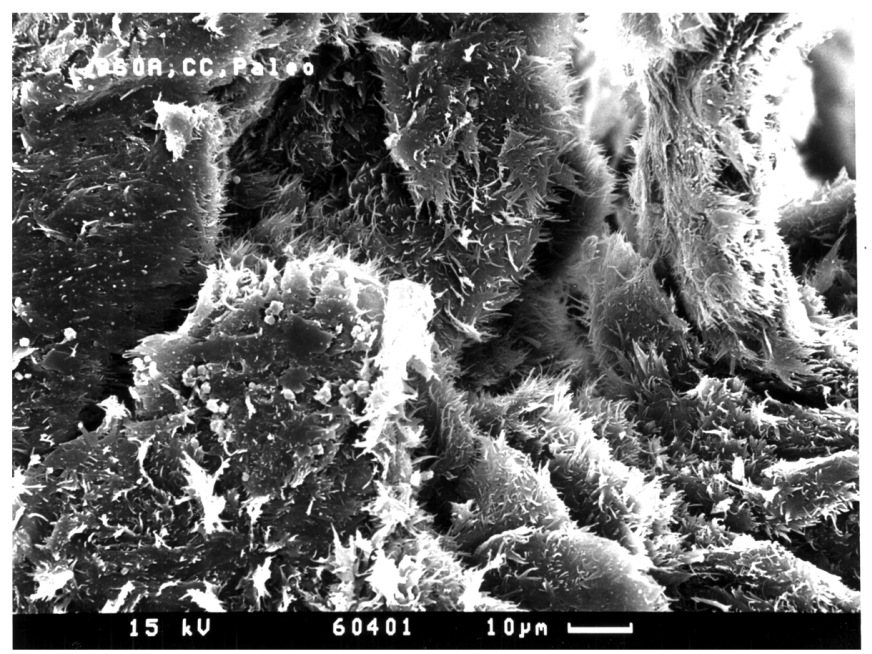

2
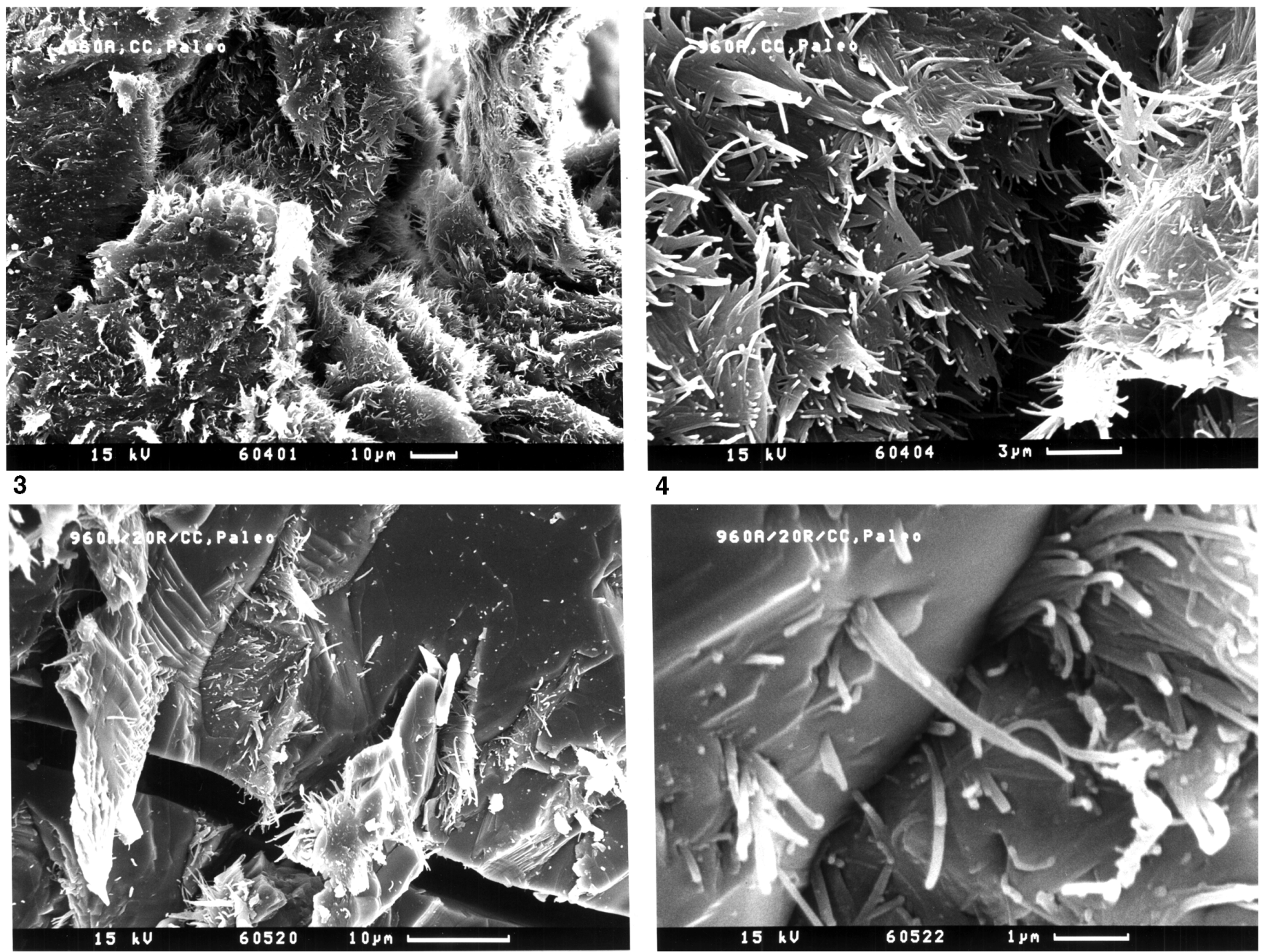

5

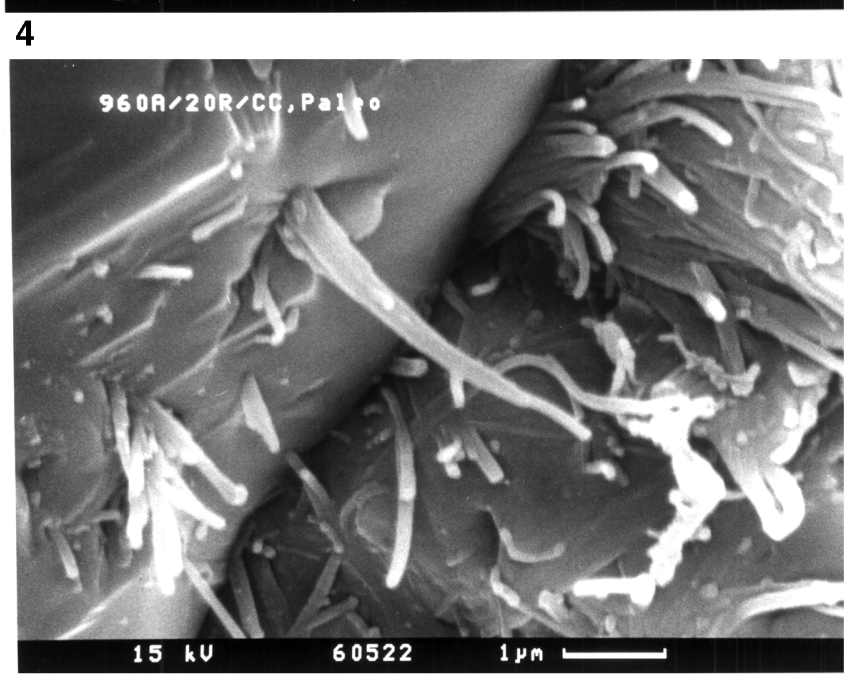

6

Plate 2. Scanning electron micrographs. 1. Sample 159-960A-19R-1, 25-30 cm, palygorskite clay with barite nodules. Overview of massive texture. 2. Detail of 1. Fibrous minerals constitute a dense web that covers an elongate mineral (zeolite?) 3. Sample 159-961A-19R-CC, Paleo-Split, palygorskite clay with barite nodules. Overview of open texture. 4. Detail of 3. Flakes are made up of curving laths which in turn consist of subparallel bundles of individual fibers of palygorskite. 5. Sample 159-960A-20R-CC, Paleo-Split, broken surface of a single barite crystal from a nodule in palygorskite clay. Palygorskite lenses in barite crystal. Note the subparallel alignment of the lenses. 6. Detail of 5. Bundles and curved, single palygorskite fibers protruding from a void in the broken barite surface. 

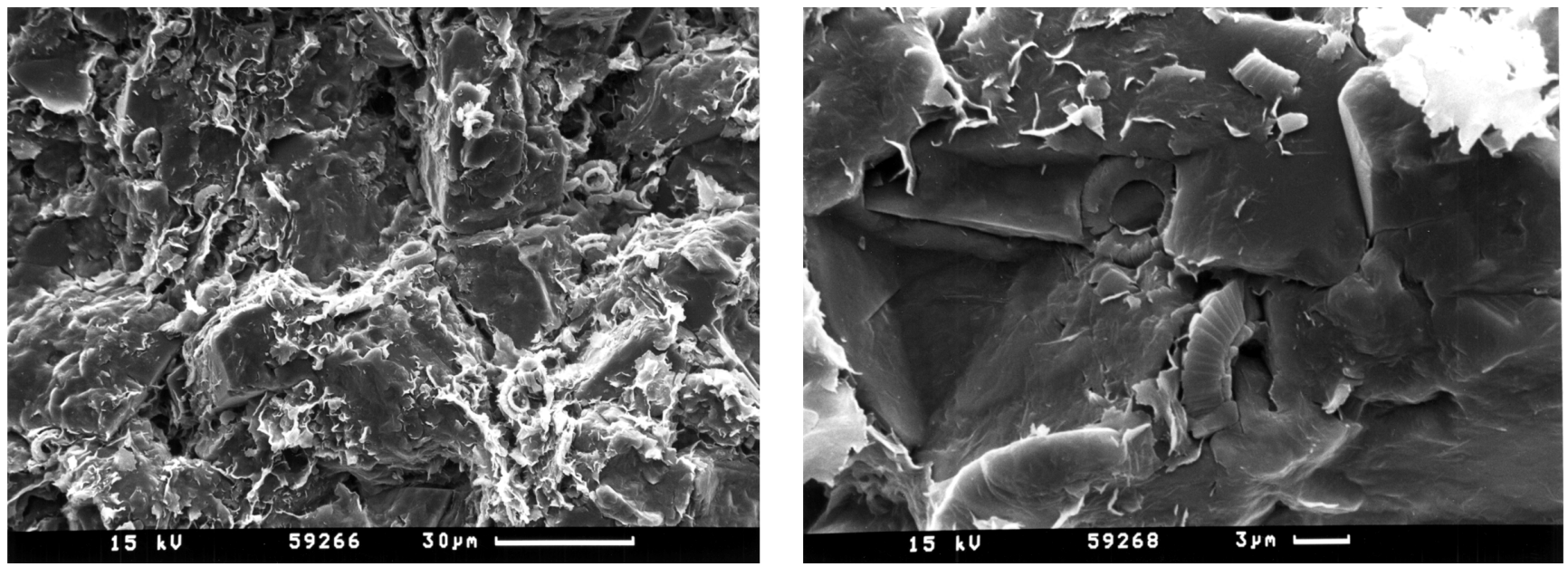

1

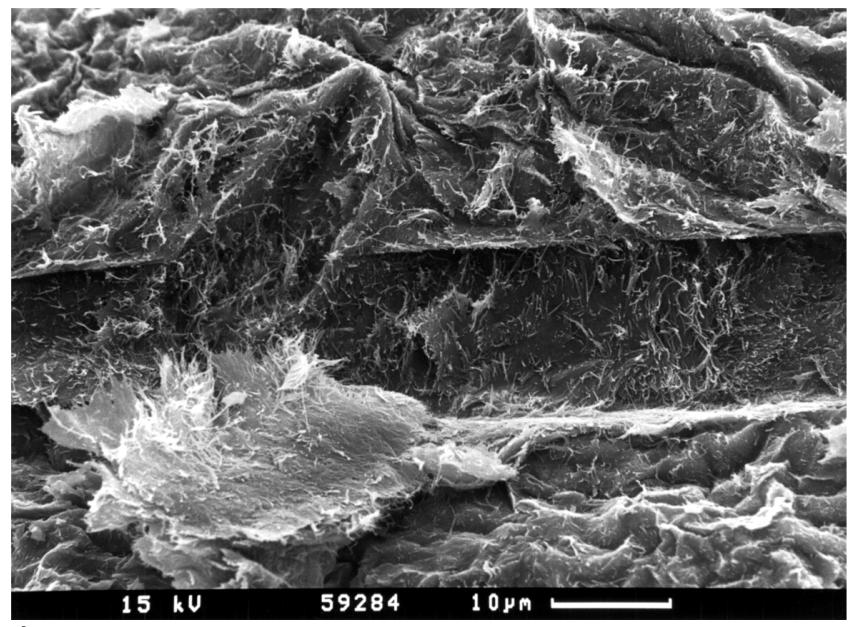

3

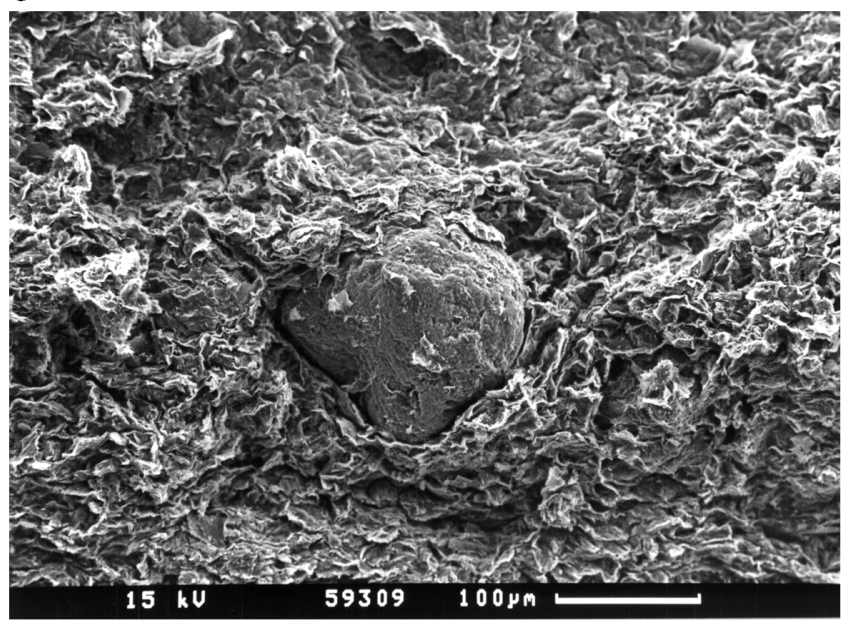

5
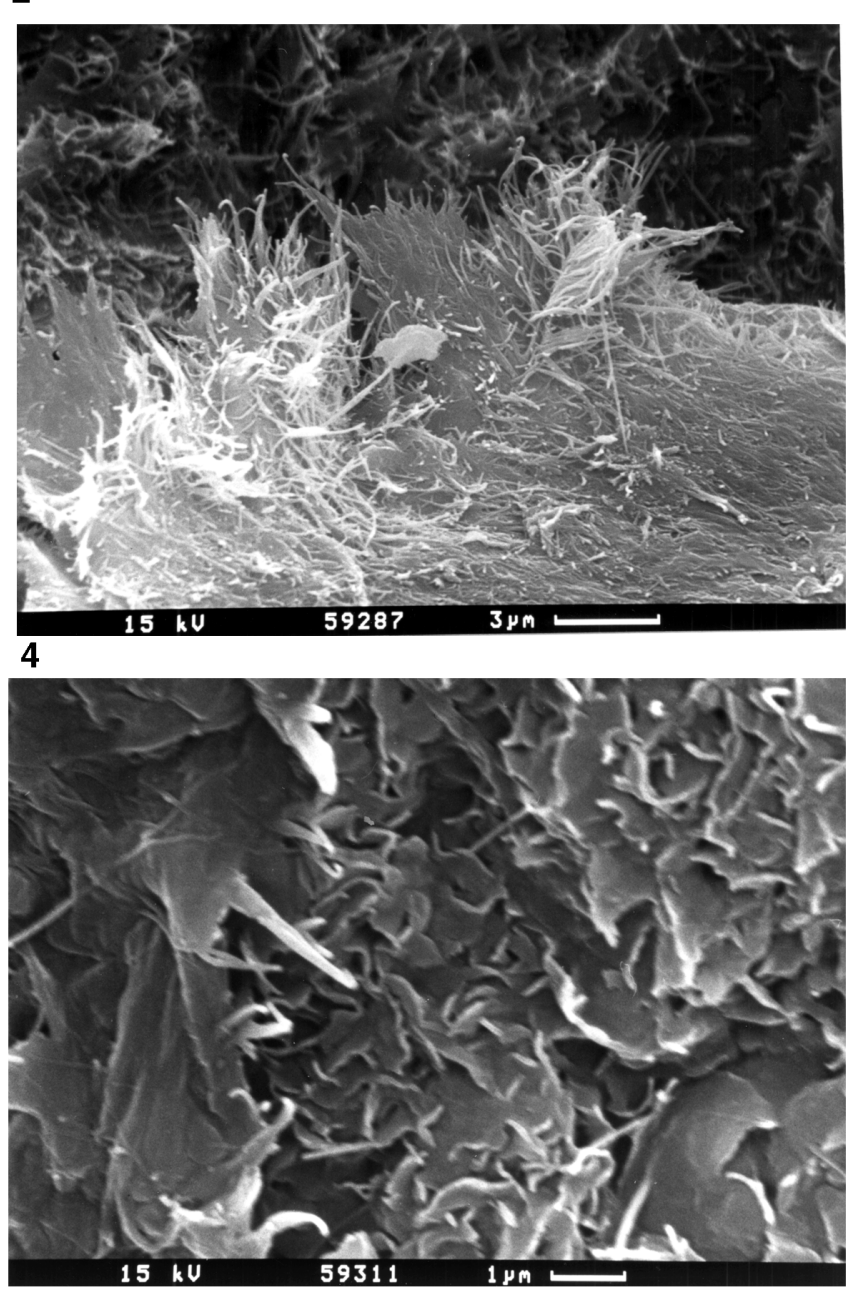

6

Plate 3. Scanning electron micrographs. 1. Sample 159-961A-19R-CC, 8-10 cm, clayey carbonate with barite crystals and calcareous nannofossils. Blocky texture with clay and calcareous nannofossils in the interstices of larger calcite grains. Coccoliths in the interstices are not overgrown and fairly well preserved. 2. Detail of 1 . Some of the coccoliths have been strongly overgrown and incorporated into the calcite blocks. 3. Sample 159-962B-8H-1, 107-109 cm, clay with zeolite. Fibrous minerals are abundant in this sample although XRD indicates only minor proportions of palygorskite (see Fig. 6). Hollow left by euhedral (zeolite?) crystal. 4. Detail of 3. Flakes of interwoven mineral fibers. 5. Sample 159-962B-8H-2, 89-94 cm, clay with zeolite and glauconite pellets. Grain in the center is a glauconite pellet. Matrix consists of irregular flakes with abundant fibrous minerals. 6. Detail of 5. Open texture of flaky minerals in glauconite grain to the right. Flake of matrix clay with fibrous minerals to the left. Note the lack of fibrous minerals in the glauconite grain. 


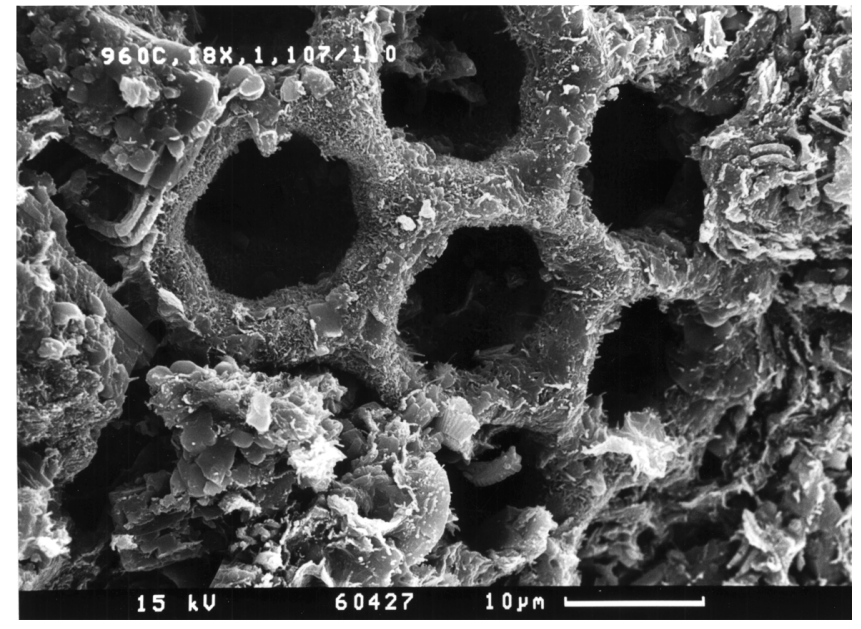

1

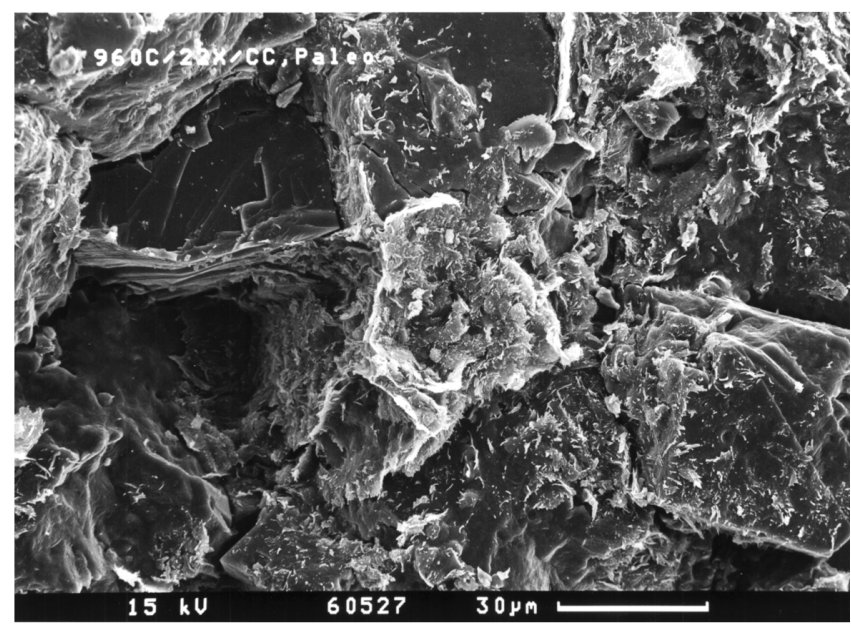

\section{3}

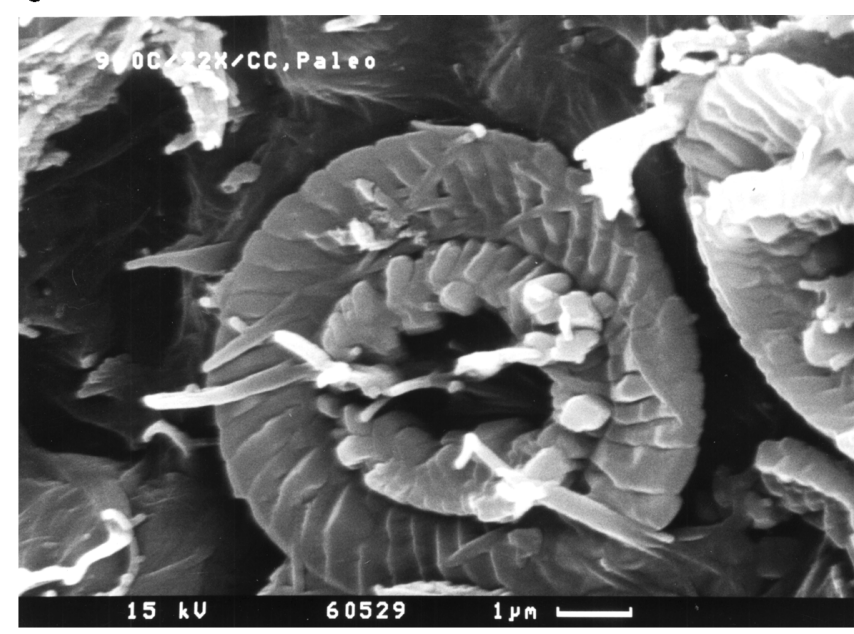

5

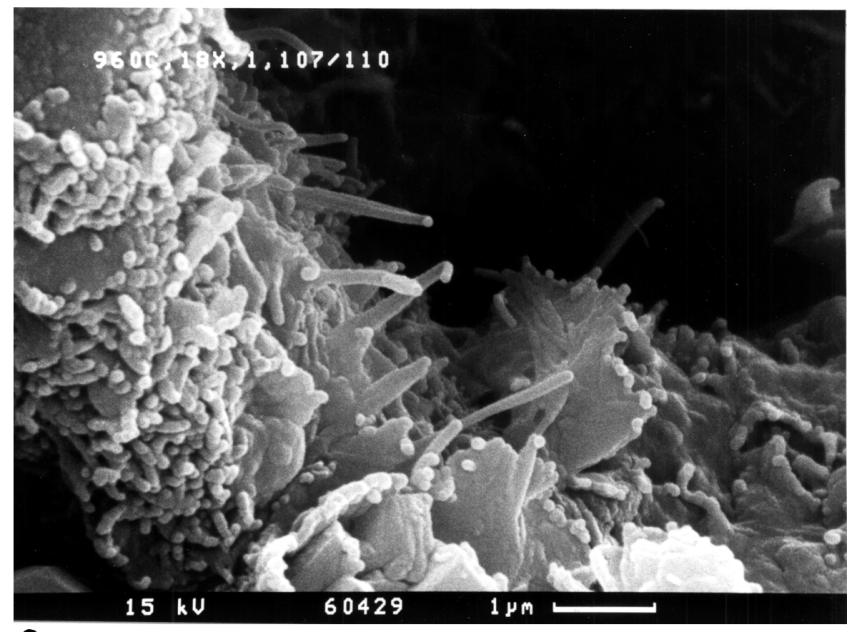

2

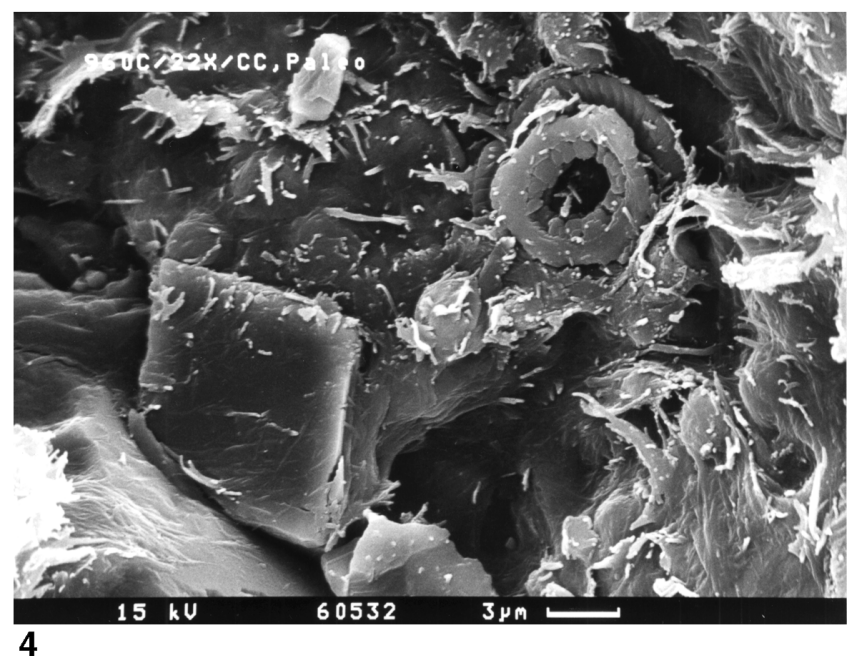

4

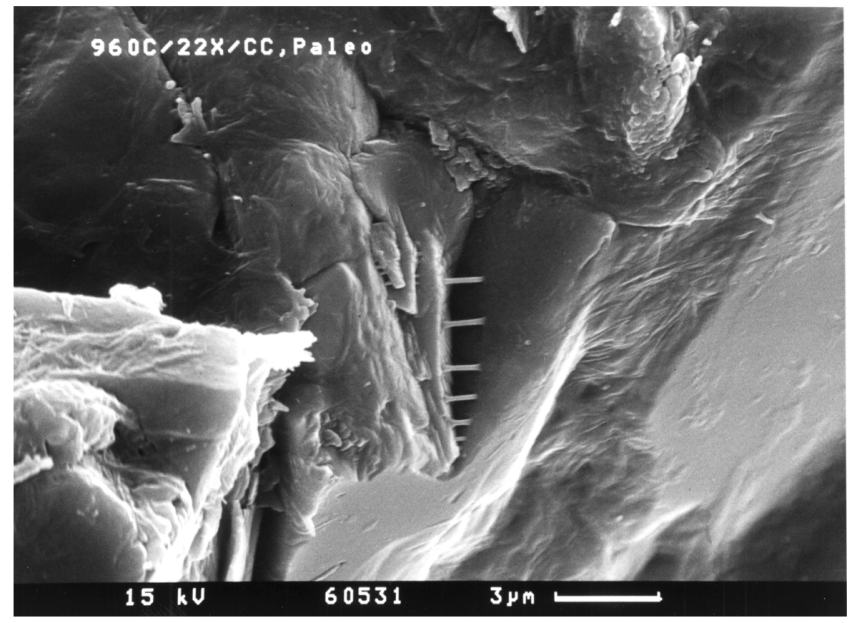

6

Plate 4. Scanning electron micrographs. 1. Sample 159-960C-18X-1, 107-110 cm, zeolitic porcellanite with nannofossils and clay. Radiolarian skeleton has completely recrystallized (probably into opal-CT). Larger, flaky minerals appear to grow from the skeletons. 2. Detail of 1. Fibrous minerals protrude from recrystallized radiolarian skeleton. Larger flake on lower right is constituted of several fibers. 3. Sample 159-960C-22X-CC, Paleo-Split, barite and dolomite siltstone. Interstices between barite and dolomite grains are filled with palygorskite clay. 4. Sample 159-960C-22X-CC, Paleo-Split, same as 3. Dolomite crystal on lower left is covered with Mg-rich silicate fibers. Moderately preserved coccolith on upper right with fibers piercing through the central opening. 5. Detail of 3. Silicate fibers growing on coccolith. Note that several fibers pierce through the central opening of the coccolith. 6. Sample 159-960C-22X-CC, Paleo-Split, same as 3. Surfaces of barite crystals on upper left are covered with palygorskite fibers. Note mineral strands between clean faces of barite crystal in the center. 